RONALDO G. DE CARVALHO
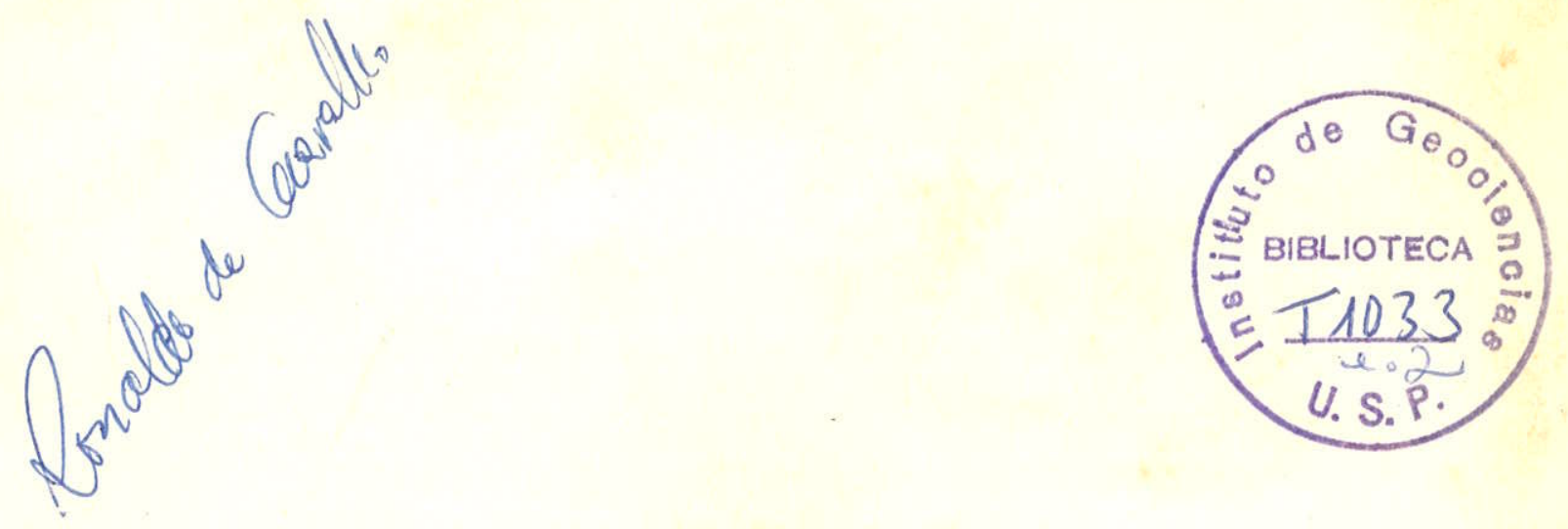

\title{
BRAQUIÓPODES DEVONIANOS DA BACIA DO AMAZONAS
}

Tese Apresentada ao Concurso de Doutoramento do Instituto de Geociências da Universidade de São Paulo.

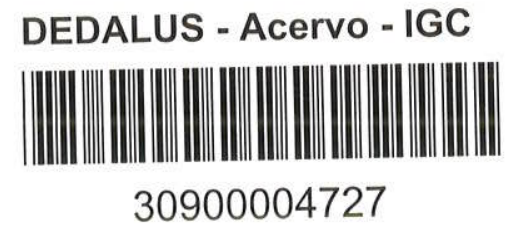


IND ICE

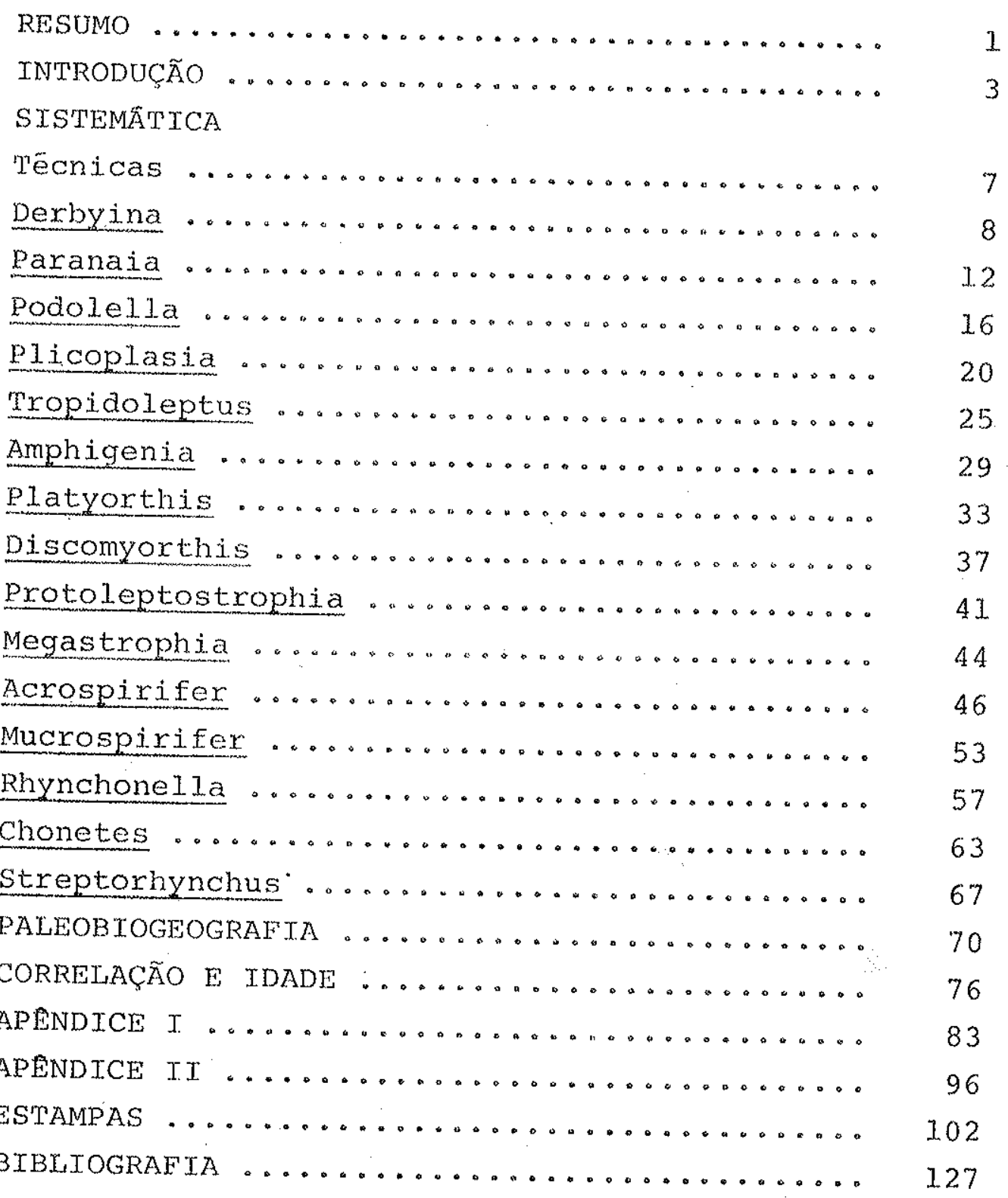


RESUMO

o objetivo principal. do presente trabalho ê um estudo de caräter sistemätico dos bra quiópodes devonianos do Estado do Pará.

O material paraense procede das For maçōes Maecuru, Ererē e Curuá.

Aproveitou-se a oportunidade para revisar, tambêm, os braquiöpodes do devoniano da Co lombia e Venezuela, que são tratados em apêndi ces neste trabalho.

Vinte foram as espëcies aqui assi naladas, as quais se distribuem pelos seguintes gê neros: Derbyina, Paranaia, Podolella, Tropidoleptus, Plicoplasia, Platyorthis, Amphigenia, Megastrophia, Protoleptostrophia, Discomyorthis, Acrospirifer, Mu crospirifer, Rhynchonella, Chonetes e Streptorhynchus. 
Vários destes gêneros são aqui iden tificados pela primeira vez.

A comparação da fauna de braquiópodes do devoniano da Amazônia com a fauna Apalachiana dos Estados Unidos da Amērica do Norte, sugere uma idade possivel entre o Emsiano e Eifiliano, pela pre sença dos gêneros Amphigenia, Discomyorthis, platiorthis e Plicoplasia.

o presente trabalho constitui revisão compreensiva dos braquiópodes do devoniano da Bacia do Amazonas desde as publicações pioneiras de Rathbun, R. (1874; 1878). 


\section{INTRODUÇÃO}

Os primeiros trabalhos versando os fósseis e a geologia do Devoniano da Amazônia, foram realizados pelos componentes das Expediçöes Morgan (1870 e 1871) e da Comissão Geolögica do Impërio do Brasil (1875 a 1878). Citam-se tambëm, entre os tra balhos pioneiros dessa região, os de Derby (1878), Rathbun (1874), Rathbun \& Hartt (1878), Smith (1879) e de Katzer (1897 e 1903). Seguiram-se os trabalhos de Clarke (1900 e 1913).

Nos ültimos anos, tem havido um con sistente progresso no conhecimento da estratigrafia dos terrenos devonianos da Bacia do Amazonas, devido, principalmente, às pesquisas realizadas pela petrobräs naquela região.

No tocante a macropaleontologia o mesmo não pode sex dito, jā que ela acha-se estacio nada desde o último trabalho feito por clarke (1913). 
Recentemente, F. W. Lange ( 1966 )

resumiu o conhecimento geolögico prëvio a respeito dos terrenos devonianos da Bacia do Amazonas, apre sentando a seguinte divisão do Devoniano daquela re gião:

3. Formação Curuá

Mb. Faro

$\mathrm{Mb}$. Curiri

Mb. Panacu

Mb. Barreirinha

2. Formação Exerē

Mb. Ariramba

Mb. Cachoeira

1. Formação Maecuru

Mb. Lontra

Mb. Jatapu 


\section{AGRADECIMENTOS}

De maneira direta ou indireta, tive a colaboração prestimosa de pessôas e instituições para a realjzação do presente trabalho.

Somos imensamente gratos ao Prof. Dr. Josué Camargo Mendes, Diretor do Instituto de Geociências da Universidade de são paulo, pela or entação, cxíticas e sugestões na preparação da tese; ao Prof. Dr. Antonio Carlos Rocha-Campos e a profa. Mary Elizabeth B. C. de Oliveira pelo apoio e esti mulo.

De um modo especial, somos agradeci dos ao Museu Nacional, pelo empréstimo de alguns braquiópodes do Devoniano da Amazonas através do Dr. Candido Simões: a Fundação de Amparo a Pesqui sa do Estado de são Paulo (FAPESP) pelo auxilio fi nanceiro à excursão de campo no ano de 1971; a Coor denação do Aperfeiçoamento de Pessoal de Nível supe rior (CAPES) pela oportunidade que tive de exami 
nar a coleção de braquiópodes do Devoniano, perten cente ao Department of Geology, oregon State Univer sity, USA, que na ocasião foi possível interessan tes comparaçōes dos espécimes estudados durante o estägio de pesquisa realizado naquele departamento sob a orientação do Prof. Dr. Arthur James Boucot.

Ao Museu Goeldi, de Belëm do Parä., estendemos também os nossos agradecimentos pelo em prëstimo de alguns espēcimes de braquiöpodes fösse is do Devoniano da Amazônia, atravês de seu Diretor, Dr. Scaff.

Somos gratos também, ao Dr. Walter Carlos Marinho e Dx. Benedito otávio Mello, pela colaboração prestada, permitindo desta forma o exa me de algumas amostras da Fetrobräs no distrito RENOR, em Belèm do parä.

A todas as pessoas e entidades men cionadas acima, manifestamos a nossa profunda grati dão. 
SISTEMĂTYCA

\section{Tëcnicas}

Na preparação dos fösseis empregaram-se mëtodos mecânicos.

Antes da obtenção dos moldes de borracha liqquida, teve-se o cuidado de banhar os es pëcimes em "solução de alvar", a fim de protegê-los contra as injürias. Os moldes de borracha foram preparados com adição de tinta nanquim ao lätex.

Recorreu-se ao branqueamento dos moldes de látex por meio da combustão de magnésio puro, com o objetivo de obter-se maior contraste principalmente com vista à documentação fotográfica.

\section{Descricões}

Os espêcimes figurados são acoman panhados de um prefixo que corresponde às iniciais das instituições que emprestaram o material para sex estudado:

MN Museu Naciona1, Rio de Janeiro, GB. MG Museu Goeldi, Belëm, PA. 
Os nümeros que são utilizados pa ra identificar os espēcimes são provisōrios.

BRACHIOPODA

Ordem TEREBRATULIDA

Subordem CENTRONELLOTDEA.

Superfamília STRTNGOCEPHALACEA King, 1850

Familia MUTATIONELLIDAE Cloud, 1942

Subfamîlia NUTATIONELIINAE Cloud, 1942

Gênero Derbyina Clarke, 1913

Derbyina jamesiana (Hartt, 1874)

Estampa 1 fj.gs. $1-11$

Retria jamesiana Hartt, Rathbun, 1874, p. 243, Est. $x$, figs. $23,27-38$.

Retzia jamesiana Hartt, Rathbun, 1878, p. 31.

Centronella jamesiana Hartt \& Rathbun, Katzer, 1.903. p. 275, Est. XII, figs. 5a,b,c.

Centronella jamesiana Hartt, Katzer, 1897, pp. 8 e 1.5.

Retzia jamesiana lartt, Clarke, 1899, p. 96. 
Material: 6 valvas ventrajs

1. valva dorsal.

Descrição: Concha pequena, contorno suboval, biconvexa, apresentando a sua major convexidade na valva ventral e a sua maior dimensão na direção longitudinal. o bico é fino, curto e en curvado.

Valva ventral: A valva ventral ë mais profunda do que a valva dorsal, iniciando a sua maior convexidade a partir do primeiro terço de seu comprimento, estendendowse pela região umbonal. o bico ëfino, curto, saliente, apresentando-se le-vemente encurvado projetando-se dorsalmente.

A ornamentação consistem em costelas que variam em nümero de 20 a 24 , as quais são simples, finas, arredondadas, separadas por sulcos de seção similar bem distintos na porção anterior da valva. Observam-se Iinhas de crescimento subcon cêntricas.

A porção mediana da valiva apre-senta um sulco pouco mais largo que as costelas adjacentes, alongando-se por toda a extensão da valva.

As placas dentais säo curtas, fi nas e obliquas à linha cardinal. 
Nos espécimes estudados por nös, a valva ventral apresenta um comprimento variando de $6 \mathrm{~mm}$ a 11 mon e a sua largura de $5 \mathrm{~mm}$ a $10 \mathrm{~mm}$.

\section{Valva dorsal: A valva dorsal}

apresenta una linha de contorno subcircular, convem xidade infexior ácuela apresentada pela valva ven tmal. obloo effino, cuxto, de pequena curvatura näo ultrapassando a inha cardinal. As costelas nes sa valva correspondem em nümero e feiçäo (forma) äs da valuva ventxal. e são bem distintas na porção an... terior da valva torrandomse, äs vezes, em alguns es pécimes quase gue imperceptiveis na regiäo umbonal. Coxrespondendo ao sulco da valva ventral, observam se na Iinha mêdia da valva dorsal, uma costela um pouco mais larga que as demais.

O compximento dessa valva nos es pectmes estudados por nôs apresenta-se variando de $5 \mathrm{~mm}$ a $10 \mathrm{~mm}$ e a largura de $4 \mathrm{~mm}$ a $8 \mathrm{~mm}$.

Dexby (1890) Forneceu a seguirn te descreâo do interior da concha: "Interjor da valva ventral com placas dentais um tanto compridas, fixadas ao fundo da valva e estendendomse para dian te até a margem extrema da placa da charneira daval. 
va oposta":

"Interior da valva dorsal com um comprido laço reflexo estendendo-se um tanto alëm do centro da valva. os ramos do laço surgem do in... terior da margem cardinal, porëm as suas bases são unidas às margens alveolares por processos horizontais e o espaço entre eles e parcialmente ocupado por alongadas calosidades achatadas que surgem das suas margens internas e se encontram ao longo da li nhà mediana, onde a junção $\vec{e}$ marcada por uma sutura mais definida no lado inferiox. Os processos laterais formam com as bases das cruras e as calosidades uma placa horizontal aa charneira furada no cen tro por um foramen arredondado ou oval. Não hä sep to ou placas alveolares e, aparentemente, nenhum processo cardinal. Adiante da margem da placa da charneira as subparalelas cruras se estendem para diante, com uma ligeixa curva para cima, numa distância curta, e, então, se curvam um tanto abruptamente para baixo, sendo o ponto da curva marcado por um esporão saliente; e então, estendendo-se para diante com uma ligeira curva para cima, são finalmente dobradas bruscamente para träs e unidas nas suas extremidades por uma cinta transversal". 
Ocorrência: Fns. Maecuru e Ererë:

\section{Discussão:}

Tudo indica que a espēcie corresponde ao gênero Derbyina. A presença de um sulco mediano um pouco mais largo que as costelas adja centes na valva ventral, afasta qualquer relação dessa espēcie com Retzia.

Concordamos com cloud, 1942, p. 121 quando esse autor afirma: "relationship to centronellidae, seems quite out of the question in view of the absence of crural plates".

\section{Gênero Paranaia Clarke, 1913}

Paranaia wardiana (Hartt, 1874)

Estampa 1, figs. 12-15

Retzia wardiana Hartt, Rathbun, 1874, p. 245, Est. X, figs. $2-5,8,9,11,12,14$ e 16 .

Retzia wardiana Hartt, Rathbun, 1878, p. 31 .

Centronella wardiana Hartt, Katzer, 1897, pp. 8, 14 è 16 . 
Retzia wardiana Hartt, Clarke, 1899, p. 96.

Centrone1la wardiana Hartt \& Rathbun, Katzer, 1903, pp. 196, 202 .

Material: 1 valva ventral e 1

Descricão: Concha pequena, 1inha de contorno subcircular, biconvexa, maior profundidade na valva ventral, bico fino e encurvado.

Valva ventral: A valva ventral apresenta a sua maior convexidade na região umbonal. o bico é curto, fino, levemente encurvado alēm da linha cardinal sobre o umbo da valva dorsal. As placas dentais apresentam-se subparalelas e curtas. A ornamentação nesta valva consiste em costelas simples, subarredondas a subangulares, variando, em nümero, de 16 a 20 nos espécimes estudados e estão separadas por sulcos de seção similar. Presença de linhas de crescimento subconcen tricas. Ausência de sinus.

O comprimento nas valvas estuda das apresenta-se variando de $8 \mathrm{~mm}$ a $11 \mathrm{~mm}$ e a largu ra de $10 \mathrm{~mm}$ a $13 \mathrm{~mm}$. 
Valva dorsal: A valva dorsai possui contorno aproximadamente circular com convexidade e tamanho menores que da valva ventral. 0 bi co è curto e ligeiramente encurvado não ultrapassan do a linha cardinal que é curta e curvada.

A ornamentação nessa valva consiste de costelas semelhantes àquelas apxesentadas pela valva ventral, tanto em nümero, formato e extensão. Presença de linhas de crescimento subconcêntricas e ausência de dobra.

Para o interior de ambas as val vas transcrevemos a descrição de Derby (1890). "Interior da valva ventral oferece placas dentais cur tas subparalelas que se estendem desde o interior do bico e se ligam ao fundo da valva."

laço alongado que se prolonga cerca de três quartos "O interior da valva dorsal tem do comprimento da valva. Os dois ramos do laço começam da margem interior da linha da charneira onde as extremidades se aderem mas, aparentemente, não formam um bem definido processo cardinal. Visto de clma, as bases dos ramos são unidas uma a outra e às margens alveolares por meio de uma placa da char neira bem desenvolvida no sentido horizontal, na 
qual as cruras acham-se tão intimamente unidas às placas laterais e às intermediärias que è quase impossivel discerni-las. Na face inferior, porëm, que não se acha colada ao fundo da valva por um sep to ou placas alveolares, as cruras são distintas, conjugadas na margem cardeal e na margem anterior da placa da charneira arqueando porëm entre estes pontos de modo a dar o aspecto de um foramen. A fa ce superior da placa da charneira apresenta uma leve depressão central correspondente, sugerindo a idéia de um foramen que, se existente, desaparecera de todos os espēcimes examinados, tendo sido fechado pela crosta de limonita com a qual o laço achase coberto espessamente. Das marcas da placa da char neira as partes livres das cruras prolongam-se para cima e para fora cerca de metade do seu comprimento dobrando-se então bruscamente para baixo e para dentro dessa dobra, caracterizando-se por esporões salientes. Quase ao centro da valva unem-se para formar um ünico comprido esporão mediano que se cur va ligeiramente para cima com direção à valva ventral. As partes separadas das cruras encerram assim um espaço em losango e em alguns espécimes o ponto onde elas se unem na frente distingue-se por 
um pequeno esporão. Sendo cobertos espessamente com limonita os ramos do laço e os três esporões sobre a sua superficie superior apresentam-se na figura muito mais grossos e mais arredondados do que realmente são."

Ocorrência: Fms. Mecuxu, Ererë

e Curuä.

\section{Gênero Podolella Kozlowski, 1929}

Podole11a derbyana (Hartt, 1874)

Estampa 1, figs. 16-18

Terebratula derbyana Hartt, Rathbun, 1874, p. 236 , Est. X, figs. 15, 17-22, 24 e 25 .

Terebratula derbyana Hartt, Rathbun, 1878, p. 35 . Terebratula derbyana Hartt, Katzer, 1897, pp. 8, 14 e 15.

Oriskania navice1la Hall \& Clarke, Katzer, 1897, p.8. Texebratula derbyana Haxtt, clarke, 1899, p. 96. 
Oxiskanla navicella Hall \& clarke, Katzer, 1903, p. 275, Est. x, figs. 9a, b.

Terebratula derbyana Hartt \& Rathbun, Katzer, 1903, p. 211, Est. XIT, figs. 7a, b.

\section{Material: uma concha.}

Descrição: Concha pequena, 1inha de contorno subpentagonal, biconvexa, com a val va ventral apresentando maior convexidade que a val va dorsal. A margem anterior ë espatulada, com $1 i^{-}$ nha de comissura retimarginada. A ornamentação no espëcime por nös estudado consta de linhas de crescimento subconcêntricas. Ausência de sinus e dobra. O seu comprimento ë de $14 \mathrm{~mm}$, largura de $10 \mathrm{~mm}$, e a sua espessura é de $5 \mathrm{~mm}$.

Valva ventral: A valva ventral apresenta maior profundidade que a valva dorsal, com a sua maior convexidade localizada na porção anterior da valva alcançando a região umbonal, declinan do suavemente para as maxgens da valva. A linha carainal é encurvada e curta. A interárea è terebratulöide, baixa, estendendo-se em toda a extensão da linha cardinal, possuindo na sua porção mëđia um 
deltirio triangular aberto. o bico é curto, suavem mente encurvado um pouco alëm do limite posterior da valva dorsal, apresentando, na sua extremidade, um foramen circular. As placas dentais são finas, sub paralelas, formando um ângulo agudo entre elas na linha cardinal, e estão estendidas atë cerca de um terço da extensão da região umbonal.

A ornamentação nessa valva, con siste em linhas de crescimento subconcêntricas. Au sência de sinus ou dobra. o comprimento da valva é de $18 \mathrm{~mm}$ e a largura de $10 \mathrm{~mm}$.

Valva dorsal: A valva dorsal ë de menor comprimento e convexidade que a valva ventral. A sua maior convexidade localiza-se na região umbonal, decrescendo para as margens da valva. A linha cardinal é encurvada e curta. o bico é fino, curto, levemente encurvado, limitado na 1inha cardinal. As fossetas dentärias apresentamme subparalelas, relativamente profundas e curtas.

Na porção mediana dessa valva, ao longo da linha de seu comprimento, observa-se uma cicatriz muito fina e rasa, correspondente ao miofragma, a qual inicia pröximo do bico extendendo-se 
até cerca de um terço do comprimento da valva dorsal. A ornamentação é representada por linhas de crescimento subconcêntricas. Ausência de dobra ou sinus. A valva dorsal apresenta um com primento de $13 \mathrm{~mm}$ e a largura de $10 \mathrm{~mm}$.

Ocorrência: Fms. Ererë, Curuä.

\section{Discussão}

Temos, somente, um espēcime, um molde interno da concha, o qual foi atribuido pox Rathbun em 1874, como sendo Terebratula derbyana Entretanto, do reestudo feito por nós desse espēcime, concluimos tratarmse de um pequeno Mutationellinae apresentando placas deltidiais pequenas e dis cretas, com linha de contorno subpentagonal, linha de comissura retimarginada, ausência de sulco, caracteristicas essas do gênero podolella de Kozlowski (cloud, 1942, p. 114). 


\begin{abstract}
Ordem SPIRIFERIDA
Subordem SPIRIFEROIDEA

Superfamĩlia CYRTIACEA Fredericks, 1919

Família AMBOCOEIIIDAE George, 1931

Superfamília AMBOCOELIINAE George, 1931

Genero Plicoplasia Boucot, 1959
\end{abstract}

Plicoplasia curupira (Rathbun, 1874)

Estampi-1, figs. 19-25

Cyrtina ? curupira Rathbun, Rathbun, 1874, p. 242, Est. $X$, figs. 1 e 6 .

Vitulina pustulosa Hall, Rathbun, 1874, p. 255, Est. IX, figs. 2, 6-8, 11-13, 15, 20, 21, 27, 32 .

Cyrtina ? curupira Rathbun, Rathbun, 1878, p. 31.

Vitulina pustulosa Hall, Rathbun, 1878, p. 36 .

Cyrtina ? curupira Rathbun, Katzer, 1897, p. 16.

Vitulina pustulosa Hall, Katzex, 1897, pp. 7, 13 e 15.

Cyrtina ? curupira Rathbun, Clarke, 1899, p. 96.

Vitulina pustulosa Ha11, Clarke, 1899, p. 96.

Cyrtina ? curupira Rathbun, Katzer, 1903, p. 211. 
Vitulina pustulosa Ha11, Katzer, 1903, pp. 194, 202, 210, Est. X, figs. 8a, b, Est. XII, figs. Ia, b, c.

Material: seis valvas ventrais e seis valvas dorsais.

Descricão: Concha de tamanho me dio, biconvexa, Iinha de contorno vaxiando, aproximadamente, de semicircular a semieliptica. A 1 inha cardinal é reta, apresentando-se um pouco inferior a máxima largura em nossos espécimes.

A concha apresenta, na valva ven tra1, uma dobra relativamente alta com um sulco na sua Iinha média, extendendo-se do bico atē a margem anterior onde torna-se mais largo. Corxespondente a esta dobra, estä presente na valva dorsal um sulco raso, largo, com uma costela mediana baixa.

A ornamentação consiste em costelas relativamente largas e linhas de crescimento subconcêntricas.

\section{Valva ventral: A valva ventral}

é convexa, com a sua major convexidade alcançando cerca de dois tercos do seu comprimento. A linha cardinal è reta. A interärea è apsaclina e apresen 
ta um deltirio triangular aberto, com sua base igual

a duas vezes a sua altura, cobrindo mais que um ter co da interārea. o bico è curto e encurvado.

A ornamentação nas valvas estudadas consiste em costelas variando em nümero de 10 a 12; são costelas simples, arredondadas, com maior largura nas suas porções anteriores.

As costelas se estendem do bico para as margens da valva, apresentando suave declinação próximo às extremidades cardinais arredondadas. Na linha média dessa valva, ao longo do seu comprimento, está localizada uma dobra formada por duas costelas de maior elevação e largura que as de mais, estando presente entre elas um sulco raso arredondado que se estende do bico da valva até a sua margem anterior. Observa-se, na região umbonal, uma cicatriz mediana, fina, deixada pelo miofragma da valva. As cicatrizes dos dentes, com linha de contorno aproximadamente triangular, são razoavelmente profundas e estão dispostas obliquamente à li nha cardinal, estando cada uma delas bordejando a cavidade deltirial na sua porção anterior.

A valva apresenta linhas de cres cimento subconcêntricas e o seu comprimento em nos- 
sos espëcimes, varia de $10 \mathrm{~mm}$ a $15 \mathrm{~mm}$, e a largura de $14 \mathrm{~mm}$ a $24 \mathrm{~mm}$.

Valva dorsal: A valva dorsal ë suavemente convexa. A linha cardinal nessa valva ë reta e longa, não alcançando porëm a mäxima largura em nossos espécimes.

o processo cardinal è alongado, elevando-se de cada um de seus lados, uma placa cru ral separada daquele por um sulco. De cada lado des sas placas crurais, localiza-se uma fosseta dentária de disposição obliqua à linha cardinal. A interārea é anaclina, estreita. A valva apresenta um sulco largo, raso, com uma costela mediana arredondada e baixa. As costelas são simples, arredondadas, relativamente largas, variando em nümero de 4 a 6 em cada lado do sulco. As linhas de crescimento são subconcêntricas.

o comprimento dessa valva apresenta-se variando de $7 \mathrm{~mm}$ a $12 \mathrm{~mm}$ e a sua largura de $13 \mathrm{~mm}$ a $18 \mathrm{~mm}$.

Ocorrência: Fms. Maecuru, Ererēe Curuä. 


\section{Discussão}

Segundo Boucot, 1959, p. 19, o gênero Plicoplasia ë caracterizado em apresentar na valva ventral uma dobra biplicada e na valva dorsal um sulco relativamente raso contendo uma costela me diana.

Boucot (1959), assinala em sino nïmia de Plicoplasia a espëcie Cyrtina \& curupira Rathbun, 1874, p. 242-243, pl. IX, figs. 1 e 6, o que concoraamos plenamente, pela revisão feita por nös.

Verificamos, tambëm, que os espécimes que vinham sendo rotulados de Vitulina pustulosa Hall in Rathbun 1874, p. 255, pl. IX, figs. $2,6,7,8,11,12,13,15,20,21,27$ e 32, são representantes desse gênero. Embora Plicoplasia apre sente similaridades com Vitulina, atualmente, consi derado pustulatia Cooper, 1956, Treatise, Vol. 2, Part H, P. H675, os espëcimes estudados por Rathbun não apresentam o septo mediano na valva ventral, o que afasta qualquer relação com Pustulatia, não nos deixando aūvida alguma em se tratar de plicoplasia. 


\begin{abstract}
Ordem ORTHIDA
Subordem DALMANELIIDINA

Superfamilia ENTELETACEA Waagen, 1884

Familia TROPIDOLEPTIDAE Schuchert, 1896

Gênero Tropidoleptus Hall, 1857
\end{abstract}

Tropidoleptus carinatus (Conrad, 1839)

Estampa 2, figs. 1-14; Estampa 3, figs. 1-3

Tropidoleptus carinatus Conrad, Rathbun, 1874, p. 254

Est. IX, fig. I e 9, Est. X, fig. 26.

Tropidoleptus carinatus Hall, Rathbun, 1878, p. 35.

Tropidoleptus carinatus Conrad, Katzer, 1897, pp.6, 13 e 15

Iropidoleptus carinatus Conrad, Clarke, 1899, p. 96.

Tropidoleptus carinatus Conrad, Katzer, 1903, p. 270, Est. $\mathrm{x}$, figs. $6 \mathrm{a}, \mathrm{b} \in 7 \mathrm{a}, \mathrm{b}$.

Material: Nove valvas ventais e nove valvas dorsais.

Descrição: Concha plano-convexa ou côncavo-convexa, apresentando maior convexidade na valva ventral. A linha de contorno varia de semi circulax a semieliptica. Nos espécimes aqui estuda- 
dos a linha cardinal è reta representando a maior largura nos espëcimes jovens, enquanto que nos adul tos a maior dimensão transversal localiza-se, aproximadamente, na parte mediana da concha.

A ornamentação consiste de costelas simples, dobra mediana na valva ventral corres pondente a um sulco na valva dorsal; linhas de cres cimento e lamelas subconcêntricas.

\section{Valva ventral: A valva ventral} è de maior convexidade que a valva dorsal, apresentando a sua maior profundidade situada no segundo tex ço do seu comprimento, decrescendo suavemente para as margens da valva. As extremidades cardinais são levemente planas.

A interárea ē bem desenvolvida alcançando em altura, aproximadamente, 98 da extensão total da linha cardinal. Presentes nessa interärea, estão um deltirio triangular aberto de altura inferior à sua base e linhas de crescimento pa ralelas à linha cardinal. Na parte posterior da ca vidade deltirial verifica-se cicatrizes musculares em forma de $\mathrm{V}$ deitado, deixadas pelo calixto.

Da área muscular flabeliforme 
dessa espécie, devido a mā condição de fossilização em nossos espēcimes, verificamse somente o seu limi te anterior deixado pelo par dos músculos didutores, destacado no primeiro terço do comprimento da valva.

$\mathrm{Na}$ sua linha mëdia, extensão lon gitudinal, observa-se a cicatriz deixada pelo miom fragma, que separa os pares de müsculos didutores e adutores dessa valva, o qual se inicia no bico estendendo-se atē o limite, aproximado, de dois terços do comprimento da valva.

As placas dentais são crenuladas, obliquas à linha cardinal, formando entre elas um ân gulo aproximado de 800 , e se iniciam na margem posterior da valva. o bico é fino e levemente encurva do alëm da linha cardinal.

o número de costelas nessa valva, nos espëcimes por nós estudados, varia de 19 a 25 e são costelas simples, arredondadas, baixas, se paradas por espaços arxedondados, rasos, de largura inferior a das costelas adjacentes.

Além das lamelas concêntricas que ornamentam essa valva, observa-se uma costela mediana de maior largura e altura, diferenciando-a 
das demais, dando um carāter de dobra na valva ventral.

Em nossos espēcimes, o comprimento da valva ventral, varia de $20 \mathrm{~mm}$ a $28 \mathrm{~mm}$ e a largura de $24 \mathrm{~mm}$ a $35 \mathrm{~mm}$.

Valva dorsal: A valva dorsal ë frequentemente plana apresentando, porēm, um sulco de maior largura que a de uma costela em sua região mediana, correspondendo à dobra na valva ventral.

A interärea é baixa. As fossetas dentārias são profundas e obliqquas à linha cardinal. o bico è curto, com pequena curvatura.

o processo cardinal, não muito preservado em nossos espécimes, è erecto e bilobado, apresentando nas proximidades da sua porção anterior dois pares de cicatrizes dos müsculos adutores.

A ornamentação consiste de 1inhas de crescimento lamelosas subconcêntricas e cos telas simples, arredondadas, que se estendem do bico para as margens da valva, e apresentam-se varian do em nümero de 23 a 25 .

O comprimento da valva dorsal",

em nossos espécimes varia de $15 \mathrm{~mm}$ a $22 \mathrm{~mm}$ e a lar-, 
gura de $20 \mathrm{~mm}$ a $30 \mathrm{~mm}$.

Ocorrência: Fms. Maecuru, Ere-

ré e curuá.

\author{
Ordem TEREBRATULIDA \\ Subordem CENTRONELIIDINA \\ Superfamïlia STRINGOCEPHALACEA King, 1850 \\ Família CENTRONELLIDAE Waagen, 1882 \\ Subfamília RENSSELAERIINAE Raymond, 1923 \\ Gênexo Amphigenia Hall, 1867
}

Amphigenia elongata (Vanuxem), 1842

Estampa 3, figs. 5-8

Amphigenia elongata Hal1, Rathbun, 1878, p. 37.

Amphigenia elongata Hall, Katzer, 1897, pp. 8 e 14.

Amphigenia elongata Hall, Clarke, 1899, p. 96.

Amphigenia elongata Hal1, Katzer, 1903, p. 202.

Amphigenia sp. Boucot, 1959, p. 762, Est. 101, figs. 4 e 5 . 
Material: duas valvas ventrais e duas valvas dorsais.

Descrição: Concha de tamanho grande, inequilateral, biconvexa. A valva ventral e de maior tamanho e convexidade que a valva dorsal. A largura mãxima da concha está localizada, normalmente, no primeiro terço de seu comprimento, na região posterior. A linha de contorno, dos espëcimes estudados por nös, apresenta-se variando de suboval a elipsoidal alongada longitudinalmente.

A linha de comissura, na margem anterior é retimarginada; nas margens laterajs ante riores apresentamse suavemente arredondada, tornando-se reta em direção do bico. A margem cardinal é subterebratulóide.

A ornamentação consiste em Iinhas de crescimento subconcêntricas circulares a subconcēntricas elipsoidais. Ausência de sinus e dobra. 
Valva ventral: A valva ventrai apresenta-se mais profunda que a valva dorsal, estando localizada a sua maior convexidade no primeiro terço de seu comprimento, na região posterior, declinando muito levemente para as margens da valva. A linha cardinal é curta e curva. o bico é curto e encurvado sobre o umbo da valva dorsal.

Em nossos espëcimes, observa-se

- molde das lamelas dentais fundidas ao septum formando o espondilium que se estende atë cerca do prí meiro terço do comprimento da valva. As placas den tais estão situadas nas margens laterais posteriores do espondilium.

A ornamentação consiste em 1inhas de crescimento subconcêntricas circulares a subconcêntricas elipsoidais.

o comprimento dessa valva apresenta-se em nossos espēcimes, variando de $65 \mathrm{~mm}$ a $105 \mathrm{~mm}$ e a largura de $45 \mathrm{~mm}$ a $46 \mathrm{~mm}$.

Valva dorsal: A valva dorsal é de menor tamanho e convexidade que a valva ventral. A linha cardinal é curta e encurvada. O bico nessa valva ë bem mais curto que aquele apresentando pela 
valva ventral.

As placas crurais, bordejando o bico, uma de cada lado, são aproximadamente paralelas apresentando, entre elas, uma suave cicatriz deixada pelo miofragma.

A ornamentação dessa valva é idên tica àquela apresentada pela valva ventral.

O comprimento da valva apresentase variando de $60 \mathrm{~mm}$ a $10 \mathrm{~mm}$ e a largura de $45 \mathrm{~mm}$ a $53 \mathrm{~mm}$.

Dada as condições de fossilização dos nossos espëcimes, não nos foi possivel observar mos qualquer impressão ou marca muscular.

Essa espëcie è possuidora de uma variabilidade muito grande entre os seus representantes, podendo ser facilmente observado entre os espēcimes estudados por nös a variaçäo do comprimen to, largura e espessura, resultando diferentes formas, tamanho e variação nas Iinhas de crescimento.

Nos espēcimes mais jovens, a largura ẽ aproximadamente, quando não igual, da mes ma dimensão que o comprimento e as linhas de crescimen to são subconcëntricas circulares; enquanto que nos adultos observa-se pequena largura em relação ao 
comprimento e as linhas de crescimento apresentamse variando de subconcêntricas circulares a subcon cêntricas elipsoidais.

Ocorrência: Fms. Mecuru, Curuä.

Ordem ORTHIDA

Subordem DALMANELILIDINA

Superfamilia DALMANELIACEA

Familia RHIPIDOMELLIDAE Schuchert, 1913

Subfamilia PLATYORTHINAE Harper, Boucot \&

Walmsley, 1969

Gênero Platyorthis Schuchert \& Cooper, 1931

Platyorthis nettoanus (Rathbun, 1874)

Estampa 4 , figs. 3 e 5

Orthis nettoana Rathbun, Rathbun, 1874, p. 247, Est. $\mathrm{x}$, figs. 7,10 e 13 .

Orthis nettoana Rathbun, Rathbun, 1878, p. 22.

Orthis nettoana Rathbun, Katzer, 1897, pp. 6, 13 e 15. 
Orthis nettoana Rathbun, Clarke, 1899, p. 96. Dalmanella nettoana Rathbun, Katzer, 1903, pp. 192, 202 e 210 .

Material: uma valva ventral e uma valva dorsal.

Descricão: Concha de tamanho mê dio, plano convexo, com convexidade na valva ventral. A linha de contorno ë subcircular. Iinha cardinal re ta e curta. A ornamentação consiste de finas costelas irradiadas do bico para as margens.

Valva ventral: A valva ventral apresenta a sua maior convexidade na região umbonal, decrescendo suavemente para as margens.

A linha cardinal é curta, reta, alcançando um terço da māxima largura em nosso espēcime. o bico é fino, curto e encurvado. A interärea ë ligeixamente anaclina, baixa, apresentando um deltirio aberto com altura aproximadamente igual à sua laxgura. As placas dentais, na porção lateral anterior do deltirio, são divergentes laterais, obliquas à linha cardinal. A área muscular é flabelifor 
me apresentando na sua porção anterior a cicatriz do par dos músculos didutores circundando na sua por çäo posterlor as impressões elipticas delxadas pelo par de adutores.

$\mathrm{Na}$ porção mediana da valva, ao longo de seu comprimento, localiza-se um miofragma, separando os pares das cicatrizes musculares, esten dendo-se atè dois terços do comprimento da valva.

A valva apresenta costelas muito finas, irradiadas de seu bico para as margens. comprimento dessa valva no espēcime estudado por nós é de $18 \mathrm{~mm}$ e a largura ē de $23 \mathrm{~mm}$.

Valva dorsal: A valva dorsal apresenta-se plana. A linha cardinal é reta e curta. o processo cardinal ë bilobado, erecto, e da sua base anterior estende-se pela 1inha média da valva um miofragma relativamente espesso na porção posterior da valva, afinando para o seu tērmino, alcançando cerca de dois terços do comprimento dessa valva. Margeando cada lado do processo 
cardinal, estão presentes as placas do braquiōforo formando entre elas um ângulo aproximado de 800 .

As fossetas dentārias säo oblĩ-

quas à linha cardinal e estão limitadas, de um lado, pela parede externa do braquióforo $e$, pelo outro lado, por uma placa da fosseta dentäria, a qual separa-se da linha cardinal, em cada lado da valva, por um sulco raso.

A ārea muscular apresenta um par de cicatrizes, deixadas pelos müsculos adutores, separado medianamente pelo miofragma.

A ornamentação consiste em costelas finas, estendendo-se do bico da valva para as suas margens.

- comprimento da valva é de 17 $\mathrm{mm}$ e a sua largura è de $20 \mathrm{~mm}$.

Ocorrência: Fms. Maecuru, Exerè e Curuā.

Discussão: 0 espëcime estudado por nōs è atribuỉdo ao gênero platyorthis, por causa de sua forma, mostrando na valva dorsal o processo cardinal bilobado de forma caracteristica desse 
gênero, bem como o campo muscular flabeliforme da valva ventral.

Ordem ORTHIDA Schuchert \& Cooper, 1932

Subordem ORTHIDINA Schuchert \& Cooper, 1932

Superfamïlia ENTELETACEA Waagen, 1884

Família RHIPIDOMELIIDAE Schuchert, 1913

Subfamilia RHIPIDOMELLINAE Schuchert, 1913

Gênexo Discomyorthis Johnson, 1970

Discomyorthis hartti (Rathbun, 1878)

Estampa 4, figs. $1-2$ e 4

Orthis harttii Rathbun, Rathbun, 1878, p. 23

Orthis harttii Rathbun, Katzer, 1897, pp. 6 e 13.

Orthis musculosa Hall, Katzer, 1897, p. 6

Orthis harttii Rathbun, Katzer, 1899, p. 96

Rhipidomel1a harttii Rathbun, Katzer, 1903, pp. 192 e 202 .

Rhipidomella musculosa Hall, Katzer, 1903, p. 194 , Est. XI, fig. 4 
Material: uma valva ventral $e^{\text {. }}$ uma valva dorsal.

Descrição: Concha biconvexa, II nha de contorno oval a aproximadamente circular. A ornamentação consiste em finas costelas. Linhas de crescimento subconcêntricas, as quais em nosso espē cime são observãveis somente na porção anterior da concha, próximoà margem antexior.

Valva ventral: A valva ventral apresenta a sua maior convexidade na porção posterior, tornando-se relativamente plana na regiāo anterior.

A interärea è estreita, apsacli na, apresentando em sua porção mëdia, um deltirio triangular aberto com sua base maior que a sua altu ra. Na borda anterior da interärea estä presente um par de placasdentais curtas.

A ārea muscular è grande, desen volvida, apresentando as impressões musculares dos adutores, alongados em sua forma, localizados na parte posterior dessa ãrea, as quals estão circunda das pelas cicatrizes do par de müsculos didutores. Um miofragma relativamente es- 
pesso na sua porção posterior estende-me do primeiro terço do comprimento da valva separando, mediana mente, as cicatrizes musculares, prolongando-se atë dois texços do total comprimento dessa valva, onde se afina e termina. Uma sërie de miofragmas menos espessos que o mediano, irradiados da porção anterior da cavidade nototirial, dividem as impressões musculares do campo muscular dessa valva.

$\mathrm{mm}$ e a sua largura ë de $30 \mathrm{~mm}$.

o comprimento da valva é de 24

\section{Valva dorsal: A valva dorsal} apresenta maior convexidade que a valva ventral, es tando a sua maiox profundidade situada na região um
bonal.

O processo cardinal é erecto ,
trilobado e, de cada lado, da sua porção lateral an terior divergem as placas do braquióforo, espessas e alongadas, formando um ângulo de 708 entre elas. ladeando as fossetas dentärias obliquas à linha car dinal.

Da porção anterior do processo cardinal estende-se, pela linha mediana da valva, um miofragma espesso na sua parte posterior separan. 
do as cicatrizes dos mūsculos adutores, tornando-se depois fino e prolongando-se atë o final do primeiro terço do comprimento dessa valva.

Apresenta essa valva, costelas

finas e irradiadas de seu bico para as margens.

o seu comprimento è de $26 \mathrm{~mm}$ e

a sua largura ê de $30 \mathrm{~mm}$.

Ocorrência: Fms. Maecuru e Curuä.

\section{Discussão}

Segundo Johnson (1970), o gênero Discomyorthis ë distinguido, facilmente, por apre sentar a valva ventral aproximadamente plana com mar cas musculares dos didutores flabeliforme, frequentemente desenvolvidas.

Para nös, a comparação do nosso espēcime com representantes do referido gênero não nos deixa dūvida em se tratar de um representante de Discomyorthis no devoniano da Anazônia, porquanto aquelas características citadas por Johnson são bem evidentes em nosso exemplar. 


$$
\begin{gathered}
\text { Ordem STROPHOMENIDA } \\
\text { Subordem STROPHOMENIDINA } \\
\text { Superfamilia STROPHOMENACEA King, } 1846 \\
\text { Familia STROPHEODONTIDAE Caster, } 1939 \\
\text { Subfamilia LEOTOSTROPHITNAE Caster, } 1939 \\
\text { Gênero Protoleptostrophia Caster, } 1939
\end{gathered}
$$

Protoleptostrophia sp.

Estampa 4, figs. 6m8; Estampa 5, fig. I

Strophodonta perplana Hall, Rathbun, 1878, p. 25.

Stropheodonta pexplana Hall, Katzer, 1897, pp. 6 e 3 .

Stropheodonta perplana Hall, claxke, 1899, p. 96.

Stropheodonta perplana Hal1, Katzer, 1903, pp. 194 e 202.

Material: quatro valvas ventrais.

Descricäo: Desta espëcie, obti vemos somente valvas ventrais, pelo qual restringim mos nossa descriç̧ão.

Valva ventral: A valva ventral apresenta-se plana, com uma ligeira convexidade na 
região umbonal. A linha de contorno é subquadrada. o bico è curto e não proeminente. A linha cardinal é reta apresentando finos denticulos na sua margem posterior. A interärea é longa, baixa, moderadamen te apisäclina.

Na linha mëdia dessa valva, ao lon go de seu comprimento, observa-se um miofragma fino estendendo-se do bico da valva, dividindo simetrica mente a ärea muscular flabeliforme, alcançando um terço do comprimento da valva.

$\mathrm{Na}$ ãrea muscular de nossos espëcimes, sö nos fol possivel observarmos as linhas de contorno laterais e anterior das cicatrizes muscula res deixadas pelos müsculos didutores, os quais são Iigeiramente triangulares.

A ornamentação consiste em costelas finas irradiadas. O comprimento varia de $14 \mathrm{~mm}$ a $42 \mathrm{~mm}$ e a largura de $16 \mathrm{~mm}$ a $50 \mathrm{~mm}$.

Ocorrência: F'ms. Maecuru e Curuã.

Discussão: Dentre os trabalhos so bre os braquiöpodos devonianos da Amazônia, dando informações sobre Stropheodonta perplana conrad ci- 
tam-se os de Rathbun, R. (1878), Katzer F. (1897 e 1903 ) e clarke J. M. (1899) que, infelizmente, não apresentam descrições e figuras dessa espëcie. Por outro lado, devido à similaridade existente entre os caracteres externos e inter nos da valva ventral de Protoleptostrophia e Leptostrophia, sö ë possivel a identificação precisà de um desses gêneros atravēs da comparação dos caracteres morfológicos internos da valva ventral.

Pelo conhecimento atual, Protoleptostrophia sobreviveu atë o fim do Devoniano Mëdio e Leptostrophia não tem sido encontrado em terrenos acima do Devoniano inferior (Williams, A., 1953, p. Entretanto, devido à presença desses espécimes junto a Amphigenia elongata, tanto na Fm. Maecuru como na Fm. Curuä, achamos mais aconselhävel as valvas aqui estudadas pertencerem ao gênexo Protoleptostrophia. 


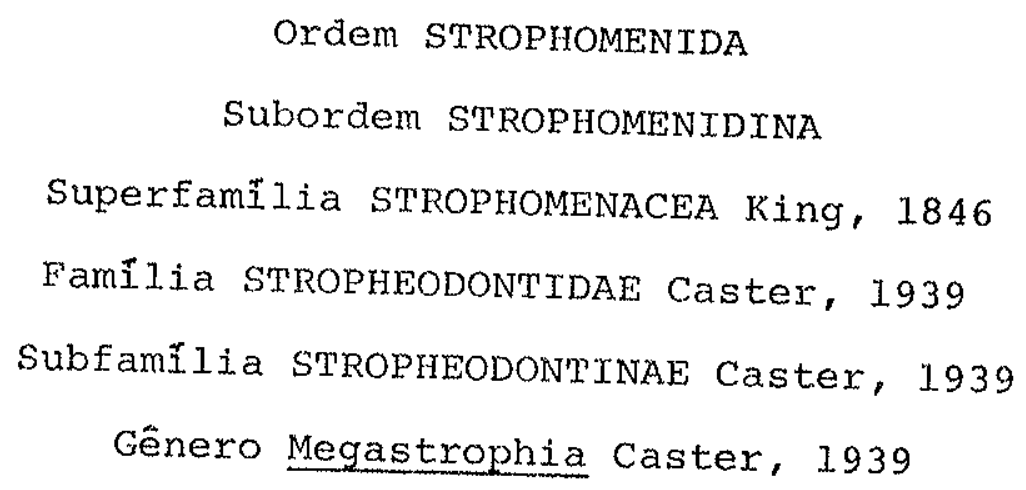

Megastrophia hoeferi (Katzer, 1903)

Estampa 5, figs. $3-4$

Stropheodonta hoeferi Katzer, Katzer, 1903, p. 270 , $1897, \mathrm{p} .6$

Est. Xx, figs. $5 a, b, c, d$.

Stropheodonta cf. concava Hall, Katzer, 1903, p.194

Material: uma valva ventral e duas valvas dorsais.

Descrição: Apesar de nossos espé-cimes apresentarem-se parcialmente quebrados, podemos deduzir ser uma concha de tamanho médio, com maior profundidade na valva ventral. A linha cardi nal ë reta.

Valva ventral: A valva ventral apresenta a sua maior convexidade na sua porção pos 
terior, na regiăo umbonal. O bico ë levemente encurvado. A valva apresenta um miofragma mediano re lativamente espesso na sua porção posterior, separando simetricamente a ärea muscular grande, flabeliforme, a qual estä representada por um par de cicatrizes dos müsculos adutores, circundados pelas cicatrizes dos müsculos didutores. Essa ärea muscu lar apresenta-se longitudinalmente estriada pela presenca de alguns pares de miofragmas radiados.

A interärea è apsclina à ortoclina. A ornamentação consiste em finas costelas. o comprimento dessa valva è de aproximadamente $25 \mathrm{~mm}$ e a sua largura ë de $30 \mathrm{~mm}$.

Valva dorsal: A valva dorsal ë plana e apresenta linha cardinal reta.

o processo cardinal é bilobado es tando bordejado, em cada lado, pelas fossetas dentä rias obliquas ä linha cardinal.

Da base do processo cardinal, de sua porção anterior, estende-se um miofragma fino separando simetricamente o par de impressōes deixa... das pelos müsculos adutores, para depois prolongarse até o meio da valva. 
A ornamentaçäo consiste : em finas costelas observäveis somente na porção anteriox da valva em estudo.

O comprimento dessa valva apreser... tawse variando de $15 \mathrm{~mm}$ a $1.7 \mathrm{~mm}$ e a sua laxgura de $20 \mathrm{~mm}$ a $24 \mathrm{~mm}$.

Ocorrència: Fm. Maecuru.

Ordem SPIRTEERTDA

Subordem SPIRTFEROIDEA

Superfamilia DELTHYRTACEA Philips, 1841

Familia DELTHYRIDAE Phillps, 1841

Subfamilita DELTHYRTNAE PhIL1ps

Gênero Acrospirifex Helmbrecht and Wedekind, 1923

Acrospirifer duodenarius (Hall)

Estampa 5, figs. 2 e 5

Spirifer duodenaria Hall, Hathbun, 1878, p. 25.

Spixifer duodenarius Hal1, Katzer, 1897, p. 27.

Spirifer duodenarius Hall, clarke, 1899, p. 96. 
Spirifer duodenarius Hall, Katzer, 1903, p. 194. Est $x, f i g s .3 a, b$.

Material: 2 valvas ventrais e uma valva doxsal.

Descxigão: Concha convexa transw versal, valva ventral com maior convexidade que a da valva dorsal. A Iinha cardinal ë reta, longa, representando a mäxima largura da concha. A interärea da valva ventral apresenta-se mais desenvolvida que a da valva dorsal. A ornamentação consism te em costelas bem definidas, arredondadas, relativamente largas. Presenca de sinus na valva ventral e dobra na valva dorsal.

\section{Valva ventral: A valva ventral} apresenta maior convexidade que a valva dorsal, estando localizada a maior profunaidade na sua porção mëdia, na região umbonal.

A Iinha cardinal é reta e longa. A interärea extende-se em toda a extensão da linha cardinal, ë bem desenvolvida, apsaclina, baixa, Ion ga, triangular, apresentando na sua porção mëaia um deltirio triangular aberto. o bico e relativam. 
mente curto, apresentando uma ligeira curvatura.

Os dentes são subovais e 1igeira-

mente arqueados. As placas dentais são curtas e di vergentes nas suas bases.

A ārea muscular è de forma aproximadamente lanceolar, apresentando na sua linha média um miofragma que separa simetricamente o par de cicatrizes deixadas pelos müsculos didutores de forma suboval. Os músculos didutores apresentam-se estria dos radialmente nas suas porções anteriores.

o nümero de costelas nessa valva ë de 10; são costelas bem definidas, arredondadas, relativamente largas.

A valva apresenta na sua porção mé dia, um sinus pouco profundo e de largura inferior às costelas adjacentes.

o comprimento apresenta-se variando de $16 \mathrm{~mm}$ a $18 \mathrm{~mm}$ e a largura de $30 \mathrm{~mm}$ a $31 \mathrm{~mm}$.

Valva dorsal: A valva dorsal $\vec{e}$ convexa transversal. A linha cardinal é reta e lon ga, representando a maior largura na valva. As extremidades cardinais apresentam-se ligeiramente pla nas com linha de contorno arredondada. o bico é cur. 
to.

A interārea é longa, baixa, aproxi madamente ortoclina.

A valva apresenta na sua linha média, ao longo de seu comprimento, uma dobra alta e de largura aproximada a duas costelas.

Em cada asa dessa valva estão presentes seis costelas, estando a sexta costela pröxi mo à extremidade cardinal quase imperceptivel. As costelas são relativamente largas, possuindo entre elas um espaço intercostal arxedondado e raso, de largura inferior às costelas acjacentes.

Observam-se linhas de crescimento subconcêntricas lamelosas.

0 seu comprimento é de $20 \mathrm{~mm} e$ a sua largura é se to ma...

Ocorrência: Fm. Maecuru.

\section{Discussão}

O gênero Acrospirifer foi criado por designação posterior de Wedkind, 1926, p. 202 (Boucot \& Johnson, 1968, p. 14), para a espécie tipo spirifer primaevus steininger, 1853. 
Na oportunidade de nosso estágio no Department of Geology, Oregon state University, USA, tivemos a oportunidade de compararmos os nossos espécimes com diversos exemplares de spirifer primaevus, o que nos facilitou muito para chegarmos a uma conclusão definida de que temos presente nos terrenos devonianos da Amazônia, representantes do gênero Acrospirifer.

Acrospirifer buarquianus (Rathbun)

Estampa 6 , figs. $1-3$ e 5

Spirifer buarquianus Rathbun, Rathbun, R.,1878, p.28

Spirifer buarquianus Rathbun, Katzer.F., 1897 II,p.7

Spirifer buarquianus Rathbun, Clarke, J.M., 1899, V. 10, p. 96

Spirifer buarquianus, Rathbun, Katzer, F., 1903, p. 272, Est. X, fig. la, b,c.

Material: Sete valvas ventrais e 12 valvas dorsais.

Descrição: A concha apresenta-se mais desenvolvida em direção transversal, com extre 
midades cardinais agudas, levemente arredondadas.

A linha cardinal é reta e coincide com a maior largura da concha.

Valva ventral: A valva ventral apresenta convexidade superior que a da valva dorsal. A Iinha cardinal é reta, longa, representando a maior largura da valva. A valva apresenta uma altura infe riox à metade da laxgura.

A interárea da valva ventral é mais desenvolvidạ que a da valva dorsal. o deltirio ë triangular, apresentando a base maior que a altura. As placas dentais são curtas não apresentando, em ex tensão, o ponto de saĩda dos dentes.

A àrea muscular è lanceolar, estriada longitudinalmente, profunda na região umbonal. Na porção média dessa área, ocorre um septo mediano, arredondado na extensão anterior.

O sinus è largo e profundo.

A valva apresenta em cada asa 12 a

15 costelas baixas e arredondadas. Observam-se 1inhas de crescimento lamelosas subconcêntricas.

O comprimento dessa valva em nossos espëcimes, varia de $19 \mathrm{~mm}$ a $25 \mathrm{~mm}$, e a largura de 
$50 \mathrm{~mm}$ a $80 \mathrm{~mm}$.

Valva dorsal: A valva dorsal apre senta menox convexidade que a valva ventral. A linha cardinal nessa valva coincide com a sua mäxima largura. A interărea é muito mais baixa que a da valva ventral.

Observa-se na região mẻdia dessa valva, uma dobra alta e estreita, correspondente ao sinus na valva ventral. Na linha média dessa dobra, na região umbonal, situa-se um septo muito fino e curto.

Devido a sua condição de fossilizą çäo não logramos distinguir as impressões musculares nessa valva.

O nümero de costelas na valva dorsal varia em mesmo nünero e forma, como aquelas apresentadas na valva ventral.

A valva apresenta linhas de cresci mento lamelosas subconcêntricas.

O comprimento desta valva apresenta-se variando, em nossos espēcimes, de $15 \mathrm{~mm}$ a 25 $\mathrm{mm}$ e a sua largura de $20 \mathrm{~mm}$ a $70 \mathrm{~mm}$. 
Ocorrência: Fm. Maecuru.

\section{Discussão:}

Espëcie muito similar, se não idẹn tica, a Acrospirifer atlanticus, variação de Acros-.pirifer hercyniae da Comunidade Rhenish, na Província Apalachiana (Boucot \& Johnson, 1967).

\section{Subfamĩlia MUCROSPIRTFINAE Boucot, 1968 Gênero Mucrospirifer Grabau, 1931}

Mucrospixifex pedroanus (Hartt, 1874)

Estampa. 6, figs. 4 e 6-9; Estampa 7, fig. 1

Spirifer pedroana Hartt, Rathbun, 1874, p. 237,

Est. VIII, figs. 2-6, 8, 9, 13-2I.

Spirifer pedroana Hartt, Rathbun, 1878, p. 27

Spirifer pedroanus Hartt, Katzer, 1897 II, p. 7,14

e 16

Spixifer peđroanus Hartt, Clarke J. M., 1899, p. 96

Spirifer pedroanus Hartt \& Rathbun, Katzer, 1903 , p. 273, Est. x, figs. 2a, b, c。 
Material: 2 valvas ventrais e 8 valvas dorsais.

Descrição: Concha biconvexa; trans versal, apresentando contorno semieliptico. A sua maior largura está localizada ao longo da linha car dinal a qual é reta e longa.

As extremidades cardinais nos espé cimes jovens formam um ângulo agudo, enquanto que nos adultos apresentam-se suavemente arredondadas.

A valva ventral apresenta um sinus pouco profundo com maior largura na sua porção ante rior. Correspondendo a este sinus localiza-se, na valva dorsal, uma dobra relativamente baixa de seção subretangular.

A ornamentação nessa concha, consiste em linhas de crescimento subconcêntricas lame losas.

\section{Valva ventral - A valva ventral} apresenta maior convexidade que a valva dorsal, localizando-se a sua maior profundidade na sua regiāo mëđia, abrangendo o umbo. o bico é fino e encurvado.

De cada lado do bico, estendendo- 
se pela região umbonal, observam-se as cicatrizes deixadas pelas dentolamelas dispostas em posição subparalelas.

A interárea è apsaclina, relativamente alta, apresentando na sua porção mēdia um del tírio triangulax aberto. o sinus da valva apresenta a sua maior largura na sua porção anterior, na qual é bem nítido as lamelas subconcêntricas.

o número de costelas apresenta-se variando de 11 a 15 em cada asa; são costelas finas, arredondadas, separadas por espaços intexcostais de largura inferior às costelas adjacentes. A valva apresenta linhas de crescimento subconcêntricas lamelosas.

o seu comprimento varia de $15 \mathrm{~mm} \mathrm{a}$ $22 \mathrm{~mm}$ e a sua largura de $24 \mathrm{~mm}$ a $32 \mathrm{~mm}$.

Valva dorsal - A valva doxsal apre senta uma convexidade inferior àquela apresentada pela valva ventral, e está localizada na sua região umbonal alcançando cerca de um terço do comprimento da valva.

As extremidades cardinais, nos espëcimes jovens, formam ângulo agudo, tornando-se li 
geiramente arredondadas e planas nos adultos. 0 bi co é fino e curto.

A interärea anaclina é muito baixa e estende-se ao longo da linha cardinal, que nessa valva representa a máxima largura.

$\mathrm{Na}$ região média, ao longo do comprimento da valva, localiza-se uma dobra, de maior largura na sua porção anterior, de seção subretangu lar. No topo dessa dobra, na sua linha mediana, es tende-se do bico da valva atë aproximadamente a sua margem anterior, um sulco fino deixado pelo miofrag ma.

Em nossos espëcimes, o comprimento dessa valva varia de $11 \mathrm{~mm}$ a $22 \mathrm{~mm}$ e a largura de $22 \mathrm{~mm}$ a $48 \mathrm{~mm}$.

Ocorrência: Fms. Maeucuru, Ererē

e Curuá. 
Rhynchonella ? sp. A

Est. 7, figs. 2-8

Rhynchone11a (Stenocisma) dotis Ha11, Rathbun, 1874, p. 246 , Est. VIII, figs. 10 e 12 .

Rhynchonella (Stenocisma) dotis ? Hall, Rathbun, 1878, Vol. XX, p. 33.

Rhynchonella (Stenocisma) dotis Hall, Katzer, 1897, II, p. 8 .

Rhynchonella dotis Ha11, Clarke J. M., 1899, Vol.10, p. 96 .

Camarotoechia cf. dotis Hall, Katzer, 1903, p. 196 e 211, Est. x, fig. 5 .

\section{Material: seis valvas ventrais e} oito valvas dorsais.

Descrição: Concha de tamanho mëdio, linha de contorno coniforme a subpentagonal. biconvexa, com maior profundidade na valva dorsal. A linha de comissura é crenulada na margem anterior da concha, tornando-se lisa e reta em direção do bico.

Valva ventral - A valva ventral apre senta a sua maior convexidade na região umbonal. A lịnha de contorno è subpentagonal. A linha cardi- 
nal è curta.

A interārea è anaclina e relativamente baixa. o bico é fino e se encurva sobre o um bo da valva dorsal.

As cicatrizes das placas dentais se apresentam obliquas ã Iinha cardinal, ladeando o bi co, uma de cada lado, projetando-se da parte posterior da interārea atë o limite antexior da região umbonal.

A valva apresenta 15 a 17 costelas arredondadas a subarredondadas, das quais 3 estão localizadas em um sulco mediano largo na sua porção anterior e, 6 a 7 costelas em cada flanco da valva. As costelas nessa valva se apresentam irradiadas, de clinando muito suavemente a partir das bordas laterais do sinus para as margens posteriores da valva.

A largura dessa valva, nos espēcimes estudados por nós, está localizada no seu primeiro terço anterior, variando de $20 \mathrm{~mm}$ a $24 \mathrm{~mm}$, o seu comprimento varia de $16 \mathrm{~mm}$ a $21 \mathrm{~mm}$.

Valva dorsal - A valva dorsal apre senta a linha de contorno de forma subpentagonal. 
malor convexidade que a valva ventral, localizada na sua porção posterior. A linha cardinal é curta.

A região umbonal è encurvada; apresenta um bico fino e curto.

Observa-se na linha mediana dessa valva uma cicatriz fina deixada pelo septo, projetando-se do bico atē o primeiro terço do comprimento dessa valva.

O nümero de costelas varia de 16 a 19; são costelas arredondadas a subarredondadas, das quais 4 a 5 estão localizadas em uma dobra mediana, larga e alta; 6 a 7 costelas estão situadas em cada flanco da valva. Essas costelas, como na valva ven tral, apresentam-se irradiadas do bico para as margens, declinando suavemente em direção das margens posteriores da valva.

A largura em nossos espëcimes apre senta-se variando de $10 \mathrm{~mm}$ a $20 \mathrm{~mm}$, e está 1ocalizada no primeiro terço anterior da valva; o compri.mento apresenta-se variando de $10 \mathrm{~mm}$ a $17 \mathrm{~mm}$.

Ocorrência: Fm. Maecuru. 


\section{Discussão:}

o espëcime aqui descrito por nös, teve a sua primeira identificação e descrição feita pox Rathbun, 1874, p. 246, Est. VII, figs. 10 e 12, baseadas em dois moldes internos de valva dorsal sem morfologia interna.

Em nossos estudos, constatamos que essas valvas possuem caracteristicas externas semelhantes às espëcies presentes no siluriano e Devoni ano.

Pela ausência de valvas exibindo as feições internas em nosso material, sugerimos, aqui, que esse espécime seja no presente momento identificado como Rhynchonella ? sp. A, para que nas pröximas oportunidades em que fizermos novas co letas, possamos contar com melhor material a fim de estudarmos a morfologia interna para uma melhor identificaçäo.

Rhynchone11a sp. B

Est. 7, figs. 10-11

Material: uma valva dorsal. 
Descrição: Consta de nossa coleção uma valva dorsal com linha de contorno subpenta gonal, convexa, apresentando a sua maior profundida de na sua porção mẻdia.

A linha cardinal é reta, curta, al cançando cerca de um terço da largura máxima da vạ va.

A linha de comissura na margem anterior ë crenulada, prolongando-se dessa forma atē cerca da metade da extensão da margem lateral, onde se torna lisa e reta em direção do seu bico. o umbo é encurvado apresentando um bico fino e curto, sugerindo uma interärea anaclina.

Na parte mëdia da valva, estä situa da uma dobra apresentando em sua região 2 costelas arredondadas e de maior largura que as demais coste las dessa valva. Essa dobra, na porção anterior da valva, apresenta uma curva brusca em ângulo aproximado de $90^{\circ}$, limitando-se um pouco alëm da margem anterior da valva, delimitada pelas demais costelas. Em cada flanco da valva estäo localizadas 7 costelas arredondadas e apresentam-se irradiadas do bico para as margens da valva, apresentando uma suave de clinação pröximo das margens posteriores. 
O comprimento da valva è de $16 \mathrm{~mm}$ e a sua largura è de $15 \mathrm{~mm}$.

Ocorrência: Fm. Maecuru.

Rhynchonella exerensis Rathbun

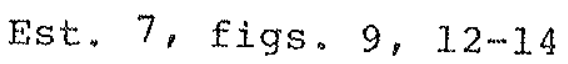

Material: uma valva dorsal. Deve-se a Rathbun (1878), pela prí meira ver, a descxição de um molde de valva dorsal atribuida a essa espëcie. Embora Rhynchonella ererensis não tenha sido ilustrada no trabalho daqueLe autor, localizamos a espëcie tipo no Museu Nacio nal. Aqui, a ilustramos com resumida descrição.

Tratamse o material de um molde in terno de valva dorsal. com linha de contorno subcircular, apresentando grande convexidade, estando a sua maior profundidade localizada na sua região anteriox.

O bico é fino, longo, encurvado.

Um septo mediano espesso na região umbonal estende-se do bico atë a metade da valva on 
de ele se torna fino.

Essa valva possui dez costelas gros sas, subarredondadas, separadas entre elas por espagos intercostais laxgos e rasos. Quatro das dez cos telas estão situadas em uma dobra mediana encurvada, aproximadamente, de $90^{\circ}$ na maxgem anterior da valva. o seu comprimento $\vec{e}$ de $28 \mathrm{~mm}$ e a sua largura ë de $27 \mathrm{~mm}$.

ocorrència: F'm. Ererë.

Chonetes comstocki Hartt

Est. 8, fig. 4

Material: duas valvas ventrais.

Dessa espëcie, obtivemos dojs exemplares de molde interno da valva ventral nos quajs baseamos a nossa descrição.

A valva ventral apresenta linha de contorno semieliptica alongada transversalmente, extremidades cardinais em angulo agudo.

Nos nossos espëcimes, a convexidade è suave. o bico é curto salientando-se muito 
pouco alëm da margem postexiox da valva. A interä... rea è baixa e longa. o septo mediano ë fino e cur. to.

Devido a escassez de material e a mal condição de fossilização de nossos espëcimes, in felizmente, näo se percebe impressões de espinhos conforme descriçäo de Rathbun (1874).

A ornamentação em nossos espëcimes consiste de costelas finas, arredondadas, estando dicotomizadas na margem anterior da valva.

A largura mäxima das valvas ventrajs estudadas por nös coincide com a linha cardi. nal e vaxia de $30 \mathrm{~mm}$ a $34 \mathrm{~mm}$; o comprimento apresen tamse variando de $15 \mathrm{~mm}$ a $20 \mathrm{~mm}$.

Ocorrência: Fm. Maecuru e Fm. Erere.

Chonetes Ereitasi Rathbun

Est. 8, figs, 1-m 2

Material: quatro valvas ventrais. 
Essa espēcie foi, pela primeira veź, descrita in Rathbun 1878, p. 18. Apesar de não ter sido figurada pelo autor acima citado, acha-se ilus trada em Katzer, 1903, Est. XII, figs. 3a, b, c.

Com base na descrição de Rathbun e estampa de Katzer, conseguimos identificar nossos exemplares da estampa 8 .

A nossa descrição, aqui. apresentada, estā baseada em moldes internos de valva ventral. Trata-se, portanto, de um resumo da descrição original com ligeiras modificações, dada à pobreza de nosso material.

Descricão: Trata-se de uma valva ventral de contorno semieliptico e extremidades car dinais aproximadamente planas formando ângulo agudo. A sua convexidade é grande a moderada em outros exem plares, apresentando a sua maior profundidade na sua porção mēdia.

Em nossas valvas o bico é curto, fino e encurvado.

A interárea è baixa e longa. Apresenta essa valva um septo mediano relativamente espesso estendendo-se do bico até cerca de um terço do 


\section{Di.scussão:}

o espécime aqui descrito por nōs, teve a sua primeira identificação e descrição feita por Rathbun, 1874, p. 246, Est. VII, figs. 10 e 12, baseadas em dois moldes internos de valva dorsal sem morfologia interna.

Em nossos estudos, constatamos que essas valvas possuem características externas semelhantes às espécies presentes no Siluriano e Devoni ano.

Pela ausência de valvas exibindo as feições internas em nosso material, sug€rimos, aqui, que esse espécime seja no presente momento identificado como Rhynchonella ? sp. A, para que nas próximas oportunidades em que fizermos novas co letas, possamos contar com melhor material a fim de estudarmos a morfologia interna para uma melhor identificação.

Rhynchonella sp. B

Est. 7, figs. 10-11

Material: uma valva dorsal. 
Descrição: Consta de nossa coleção uma valva dorsal com linha de contorno subpenta gonal, convexa, apresentando a sua maior profundida de na sua porção média.

A linha cardinal é reta, curta, al cançando cerca de um terço da largura mäxima da val va.

A linha de comissura na margem anterior é crenulada, prolongando-se dessa forma até cerca da metade da extensão da margem lateral, onde se torna lisa e reta em direção do seu bico. o umbo é encurvado apresentando um bico fino e curto, sugerindo uma interārea anaclina.

Na parte média da valva, estā situa da uma dobra apresentando em sua região 2 costelas arredondadas e de maior largura que as demais coste las dessa valva. Essa dobra, na porção anterior da valva, apresenta uma curva brusca em ângulo aproximado de $90^{\circ}$, limitando-se um pouco além da margem anterior da valva, delimitada pelas demais costelas. Em cada flanco da valva estäo localizadas 7 costelas arredondadas e apresentam-se irradiadas do bico para as margens da valva, apresentando uma suave de clinação próximo das margens posteriores. 
O comprimento da valva è de $16 \mathrm{~mm}$ e a sua largura ê de $15 \mathrm{~mm}$.

Ocorrência: Fm. Maecuru.

Rhynchonella ererensis Rathbun

Est. 7, figs. 9, 12-14

Material: uma valva dorsal.

Deve-se a Rathbun (1878), pela pri

meira vez, a descrição de um molde de valva dorsal atribuĩda a essa espécie. Embora Rhynchonella ererensis não tenha sido ilustrada no trabalho daquele autor, localizamos a espécie tipo no Museu Nacio nal. Aqui, a ilustramos com resumida descrição.

Trata-se o material de um molde in terno de valva dorsal com linha de contorno subcircular, apresentando grande convexidade, estando a sua maior profundidade localizada na sua região anterior.

o bico é fino, longo, encurvado.
Um septo mediano espesso na região

umbonal estende-se do bico até a metade da valva on 
de ele se torna fino.

Essa valva possui dez costelas gros sas, subarredondadas, separadas entre elas por espaços intercostais largos e rasos. Quatro das dez cos telas estão situadas em uma dobra mediana encurvada, aproximadamente, de $90^{\circ}$ na margem anterior da valva. o seu comprimento é de $28 \mathrm{~mm}$ e a sua largura è de $27 \mathrm{~mm}$.

Ocorrência: Fm. Ererē.

Chonetes comstocki Hartt

Est. 8, fig. 4

Material: duas valvas ventrais.

Dessa espécie, obtivemos dois exemplares de molde interno da valva ventral nos quais baseamos a nossa descrição.

A valva ventral apresenta linha de contorno semieliptica alongada transversalmente, extremidades cardinais em ängulo agudo.

Nos nossos espécimes, a convexidade é suave. o bico é curto salientando-se muito 
pouco além da margem posterior da valva. A interārea é baixa e longa. O septo mediano é fino e curto.

Devido a escassez de material e a mal condição de fossilização de nossos espécimes, in felizmente, não se percebe impressões de espinhos conforme descrição de Rathbun (1874).

A ornamentação em nossos espécimes consiste de costelas finas, arredondadas, estando dicotomizadas na margem anterior da valva.

A largura māxima das valvas ventrais estudadas por nós coincide com a linha cardinal e varia de $30 \mathrm{~mm}$ a $34 \mathrm{~mm}$; o comprimento apresen ta-se variando de $15 \mathrm{~mm}$ a $20 \mathrm{~mm}$.

Ocorrência: Fm. Maecuru e Fm. Ereré.

Chonetes freitasi Rathoun

Est. 8, figs. 1-2

Material: quatro valvas ventrais. 
Essa espécie foi, pela primeira veż, descrita in Rathbun 1878, p. 18. Apesar de não ter sido figurada pelo autor acima citado, acha-se ilus trada em Katzer, 1903, Est. XII, figs. 3a, b, c.

Com base na descrição de Rathbun e estampa de Katzer, conseguimos identificar nossos exemplares da estampa 8 .

A nossa descrição, aqui apresentada, está baseada em moldes internos de valva ventral. Trata-se, portanto, de um resumo da descrição original com ligeiras modificações, dada à po breza de nosso material.

Descrição: Trata-se de uma valva ventral de contorno semieliptico e extremidades car dinais aproximadamente planas formando ângulo agudo. A sua convexidade é grande a moderada em outros exem plares, apresentando a sua maior profundidade na sua porção média.

Em nossas valvas o bico é curto, fino e encurvado.

A interárea é baixa e longa. Apresenta essa valva um septo mediano relativamente espesso estendendo-se do bico até cerca de um terço do 
comprimento total da valva.

A ornamentação consiste em costelas finas, sendo porẻm, um pouco mais espessas que aquelas apresentadas pela espëcie Chonetes camstocki, e estão irradiadas do bico para as margens da valva.

A largura máxima dessa valva está localizada ao longo de sua linha cardinal, e em nos sos espécimes varia de $26 \mathrm{~mm}$ a $30 \mathrm{~mm}$; o comprimento apresenta-se variando de $15 \mathrm{~mm}$ a $20 \mathrm{~mm}$.

Ocorrência: Fm. Maecuru, Fm. Ereré e Fm. Curuā.

Chonetes onettianus Rathbun

Est. 8, fig. 3

Material: uma valva ventral.

Dessa espécie, obtivemos uma valva ventral convexa com linha de contorno semieliptica estando a sua maior largura localizada ao longo da linha cardinal.

As extremidades cardinais apresen- 
tam-se ligeiramente arredondadas.

A valva apresenta um bico fino

e curto.

Um septo mediano, pequeno e fino, estende-se cerca de um quarto do comprimento da val va.

A ornamentação consiste em costelas muito finas, embora não se apresentem muito bem distintas em nosso exemplar.

o comprimento da valva em questão é de $9 \mathrm{~mm}$ e a sua largura de aproximadamente $12 \mathrm{~mm}$.

Ocorrência: Fm. Ererē.

Streptorhynchus agassizi Hartt Est. 8, figs. 5-12

Material:

Descrição baseada em moldes internos de valva ventral. 
Valva ventral - A valva ventral apre senta uma linha de contorno de forma aproximadamente circular.

Apresenta convexidade, estando 10calizada a sua maior profundidade na região umbonal, abrangendo a parte média dessa valva, para depois decrescer em direção ās margens, onde em alguns espēcimes apresentam a região anterior relativamente plana.

As extremidades cardinais em algumas de nossas valvas se apresentam ligeiramente encurvadas, não ultrapassando porém a linha da charnei ra.

o bico é curto, pouco encurvado, ul trapassando muito pouco a linha da margem posterior da valva.

A ārea cardinal é triangular, baixa, de extensão um pouco menor que a linha cardinal, e apresenta placas dentais curtas e rasas.

Dado ao mau estado de fossilização de nosso material, não nos foi possỉvel observarmos qualquer impressão de músculos.

A ornamentação nessa valva é constituída de finas costelas arredondadas, e apresen- 
tam-se bifurcadas, aproximadamente, a partir da par te média da valva e se irradiam do bico para as mar gens da valva.

Em nossos espécimes o comprimento dessa valva varia de $18 \mathrm{~mm}$ a $25 \mathrm{~mm}$ e a largura de $23 \mathrm{~mm}$ a $30 \mathrm{~mm}$.

Ocorrência: Fms. Maecuru, Ererē e curuã.

Discussão: Obtivemos vārios moldes internos de valva ventral de Streptorhynchus na região do Ereré. Pelas suas formas assemelham-se muito a espécie descrita por Rathbun (1874), p. 248. Embora as ilustrações de Rathbun apresentadas na Est. IX sejam de má qualidade, achamos que condizem muito com os espécimes aqui estudados por nós. 


\section{PALEOBIOGEOGRAFIA}

Os braquiópodes do Devoniano Inferior da Bacia do Amazonas correspondem a uma assem blëia de fósseis constituída na maioria por gêneros presentes na Província Apalachiana, do que os registrados na Província Malvinokaffrica ou na Província Velho Mundo.

Amphigenia, é um gênero restrito. à Província Apalachiana (Boucot, Johnson \& Talent , 1969).

O gênero Amphigenia tem sido registrado no Devoniano, Emsiano - Eifiliano, da costa Este da América do Norte (Boucot \& Johnson, 1967). No Devoniano do Norte da África, a presença desse gê nero tem sido demonstrada por Villemur \& Drot (1957), Drot (1966) e, Boucot, Johnson \& Talent (1969).Trapp (1968), assinala a presença de Amphigenia na Formação Floresta, Devoniano Inferior da Colômbia, bem co mo Liddle, Harris \& Wells (1943) no Devoniano da Venezuela. No Brasil, é de grande significado a presença de Amphigenia no Devoniano da Bacia do Parnaí- 
ba, assinalado por Kegel (1953).

Acrospirifer, gênero registrado no Devoniano da Amazônia, ē representado nas províncias Apalachiana e Velho Mundo. Na primeira, além de sua ocorrência no Devoniano da costa Este da América do Norte (Boucot, Johnson \& Talent, 1969) está também presente no Devoniano de Nevada (Johnson, 1970). No Devoniano Inferior da Colômbia, como representante apalachiano, esse gênero é assinalado em Trapp (1968). Na Provincia Velho Mundo, o gênero Acrospirifer acha-se registrado na costa Oeste da Eu ropa (Boucot, Johnson \& Talent, 1969).

Discomyorthis è um gênero que è distinguido facilmente dos gêneros Dalejina e Rhipidomella, pela caracteristica de apresentar a valva ventral aproximadamente plana, com marcas musculares dos didutores flabeliforme e frequentemente desenvol vidas (Johnson, 1970).

Segundo Boucot (em publicação), o gênero Discomyorthis é restrito à Província Apalachiana. Representantes desse gênero estão registrados no Devoniano de Nevada (Johnson, 1970), no Devoniano da costa Este da Amërica do Norte (Boucot, informação oral: em publicação). Discomyorthis é re- 
portado em Trapp (1968) na Formação Floresta, Devoniano Inferior da Colômbia; está presente também no Devoniano Inferior da Venezuela (Liddle, Harris \& Wells, 1943) e no Devoniano Inferior da Manchüria (Hamada, 1971).

Megastrophia è outro gênero tambêm restrito à Província Apalachiana (Boucot, Johnson \& Talent, 1969), que ocorre no Devoniano Inferior da Amazônia.

Esse gênero apalachiano está assi nalado no Devoniano da costa Este da América do Nor te (Boucot, Johnson \& Talent, 1969) e no Devoniano de Nevada (Johnson, 1970). Megastrophia acha-se re gistrado em Caster (1939), Devoniano da Colômbia. Liddle, Harris \& Wells (1943), assinalam esse gênero no Devoniano da Venezuela, bem como Hamada (1971) registra a presença de Megastrophia no Devoniano In ferior da Manchüria.

\section{Segundo Boucot, Johnson \& Talent} (1969), Plicoplasia é um gênero restrito à Província Apalachiana e Província Malvinokaffrica. Plicoplasia na Província Apalachiana é registrado em terrenos de Oris- 
kany a Schoharie, Devoniano Inferior da costa Este: da Amërica do Norte (Boucot, Johnson \& Talent, 1969), bem como no Devoniano de Nevada (Johnson, 1970). Nos terrenos do Devoniano Infe rior da Colômbia, plicoplasia estā registrado em Trapp D. (1968). A presença desse gênero na Provín cia Malvinokaffrica è assinalado em Boucot, Johnson \& Talent (1969), no Devoniano do Sul da Åfrica.

Platyorthis, gênero restrito à Pro vincia Apalachiana (Boucot \& Johnson, 1967) e Velho Mundo (Boucot \& Johnson, 1967) estā também represen tado no Devoniano Inferior da Bacia do Amazonas.

De acordo com Boucot (informação oral: em publicação), esse gênero estā presente no Devoniano da costa Este da América do Norte e da costa Oeste da Europa. Platyorthis é reportado em Trapp (1968), nos terrenos devonianos da Colômbia ; está presente também no Devoniano Inferior da Venezuela (Liddle, Harris \& Wells, 1943).

Protoleptostrophia, gênero que se gundo Boucot, Johnson \& Talent (1969) é restrito às Provincias Apalachiana e Malvinokaffrica, acha-se tambëm registrado no devoniano norte brasileiro.

Na Provincia Apalachiana, o gêne-- 
ro Protoleptostrophia está assinalado no Devoniano da costa Este da América do Norte (Boucot, Johnson \& Talent, 1969). Em terras do Devoniano Inferior da Colômbia, esse gênero acha-se registrado em Trapp (1968). Liddle, Harris \& Wells (1943), demonstra a presença desse gênero no Devoniano Inferior da Vene zuela. Boucot, Johnson \& Talent (1969, p. 28) assi nalam o gênero protoleptostrophia na Província Mal vinokiaffica, Devoniano do Paranä.

Outro gênero que acha-se represen tado no devoniano norte brasileiro é Podolella.

Na Província Apalachiana esse gênero está registrado no Devoniano da costa Este da América do Norte (Boucot \& Johnson, 1967) e, na Pro vîncia Velho Mundo é encontrado no Devoniano Inferior da Europa (Cloud, 1942).

Tropidoleptus, gênero assinalado no Devoniano da Amazônia, estā registrado no Devoniano da costa Este da Amërica do Norte, Provincia Apalachiana, apresentando uma distribuição estratigráfica a partir do Givetiano ao Fransniano (Boucot, Johnson \& Talent, 1969). No Devoniano Inferior da Colômbia, esse gênero ē registrado em Morales (1965). Na Província Malvinokaffrica, o 
'gênero Tropidoleptus está representado no Devoniano da Bolĩvia com distribuição estratigräfica Emsiano ao Eifiliano (Boucot, Johnson \& Talent, 1969), Kozlowski (1923) e Branisa (1965).

Na costa Oeste da Europa, esse gê nero estā assinalado no intervalo de tempo Gediniano ao Emsiano, na Província Velho Mundo (Boucot , Johnson \& Talent, 1969).

Segundo Boucot \& Harper (1968) ,

- gênero Anoplia, na Provỉncia Apalachiana, ocorre no Devoniano Inferior, Gediniano superior - Emsiano da costa Este da América do Norte e no intervalo de tempo Siegeniano ao Emsiano do Devoniano de Nevada. Esse gênero como representante apalachiano, está registrado no Devoniano Inferior da Colômbia (Trapp, 1968).

Na Província Velho Mundo, o gênero Anoplia ocorre na costa Oeste da Europa, em terrenos do Devoniano Inferior, nas comunidades Rhenish - Bohemian (Boucot \& Harper, 1968). 


\section{CORRELAÇÃO E IDADE}

A fauna de braquiópodes do Devoniano da Bacia do Amazonas, estudada por nōs, inclui cerca de 20 espécies entre as quais 10 pertencem a gêneros identificados pela primeira vez.

A correlação e idade em nosso tra balho è dada obedecendo-se a ordem genérica onde a distribuição estratigráfica de alguns gêneros selecionados foram examinadas e comparadas para uma melhor situação da idade da fauna.

Analisando, na tabela 1, a distrí buição estratigrăfica dos principais gêneros de bra quiōpodes conhecidos por nōs, no Devoniano da Bacia do Amazonas, verifica-se uma nitida e intima relação com os gêneros presentes na Província Apalachia na, Devoniano da costa Este da América do Norte.

Dentre os gêneros assinalados na

fauna de braquiópodes da Amazonia, correlacionáveis aos gêneros apalachianos da costa Este da América do Norte, citamos: Amphigenia, Acrospirifer, Discomyorthis, Mucrospirifer, Megastrophia, Plicoplasia, Protoleptostrophia, Podolella, Platyorthis, Tropidoleptus e Anapolia. 
O gênero Amphigenia no Devoniano da bacia do Amazonas, está representado pela espécie Amphigenia elongata (Vanuxem), apresentando dis tribuição estratigráfica restrita as Formações Scho harie e Onondaga, Emsiano ao Eifeliano, Devoniano Inferior da costa Este da América do Norte, Provincia Apalaćhiana (Boucot, Johnson \& Talent, 1969). Segundo Boucot (1967), a ocorrência do gênero Amphigenia em terrenos de idade inferior ao Eifeliano, è desconhecida no mundo.

Acrospirifer, é outro gênero que, no presente momento, possui dois representantes assinalados nos terrenos devonianos da Amazônia:

Acrospirifer duodenarius (Hall), espēcie presente no devoniano norte brasileiro, apresenta uma distribui Ção estratigráfica Emsiano ao Eifiliano, na Província Apalachiana da costa Este da América do Norte ; estä assinalada na Zona Amphigenia, no intervalo Schoharie - Onondaga (Boucot \& Johnson, 1967).

O segundo representante do gênero Acrospirifer no Devoniano da Amazônia, é a espécie Acrospirifer buarquianus (Rathbun) a qual é muito si: milar, se năo idêntica, à espécie Acrospirifer atlanticus, que segundo Boucot \& Johnson (1967), pode ser 
uma variação de Acrospirifer hercynae (Emsiano inferior da Comunidade Rhenish) na Província Apalachia na, costa Este da América do Norte, com distribuição estratigráfica restrita a Formação schoharie, de idade Emsiano (Boucot \& Johnson, 1967).

Discomyorthis e Platyorthis são dois gêneros presentes, sem dūvida alguma, no Devoniano da Amazônia representados, respectivamente , pelas espēcies Discomyorthis hartti (Rathbun) e platyorthis nettoanus (Rathbun).

A distribuição estratigrāifica des ses dois gêneros no Devoniano apalachiano da costa Este da América do Norte, está situada entre os intervalos de tempo Gediniano superior ao Eifeliano (Boucot \& Johnson, 1967).

Plicoplasia, de distribuição estratigráfica Siegeniano superior ao Eifiliano, è ou tro gênero da Província Apalachiana (Boucot \& Johnson, 1967) que acha-se representado no devoniano norte brasileiro, pela espécie plicoplasia curupira (Rathbun).

Mucrospirifer, Megastrophia e Protoleptostrophia. Esses três gêneros estão assinala dos no Devoniano da costa Este da Amërica do Norte, 
Provincia Apalachiana, apresentando semelhantes dis tribuições estratigräficas, siegeniano superior ao Gevediano superior (Boucot \& Johnson, 1967).

As espëcies representativas desses três gêneros no Devoniano da Amazônia são, respectí vamente, Mucrospirifer pedroanus (Hartt), Megastrophia hoeferi (Katzer) e Protoleptostrophia sp.

Podolella, gênero registrado no intervalo de tempo Gediniano inferior ao Gediniano superior, Devoniano da costa Este da América do Nor te, Província Apalachiana (Boucot \& Johnson, 1967), está também assinalado no devoniano norte brasileiro pela espēcie Podolella derbyana (Hartt).

Outro gênero registrado no Devoniano Inferior da Amazônia é Tropidoleptus que na Província Apalachiana, costa Este da América do Nor te, apresenta distribuição estratigráfica a partir do Givetiano ao Fransniano (Boucot \& Johnson \& Talent, 1969).

O gênero Anoplia nas Formações Mae curu e Curuá, do Devoniano Inferior da bacia do Ama zonas, está representado pela espécie Anoplia nucleata (Hall) (Chonetes nucleata Hall in Clarke J.M. , 1899, Vol. 10, p. 96) e Anoplia nucleata Hall in Kat 
zer F., 1903, pp. 194 e 202. Segundo Boucot \& Harm per (1968), o gênero Anoplia, na Provincia Apala chiana, apresenta uma distribuição estratigräfica a partix do Gediniano superior ao Ensiano superior. Dessa assemblëia de braquiöpodes do Devoniano da Amazônia, onde encontramos värios gênexos restritos ou comuns à Provĩncia Apalachiana no Devoniano Inferior da costa Este da América do Norte, a presença dos gëneros Discomyorthis, plaw tiorthis, plicoplasia com o limite de distribuiçäo estratigräfica não uItrapassando o Eifiliano para o Devoniano Médio, ë reforçada pela ocorrência do gêm nexo Amphigenia que apresenta uma completa evolução (Boucot, 1959) e zoneamento restrito as Formaçöes Schoharie e Onondaga (Boucot \& Johnson, 1967), que nos sugere uma idade situada entre o Emsiano ao Eifiliano paxa a fauna de braquiöpodes do Devoniano da bacia do Amazonas. 
TABELA 1

Ocorrência de gênexos de braguiōpodes do Devoniano Inferior na Provîncia Apalachiana, segundo Boucot: Johnson (1967)

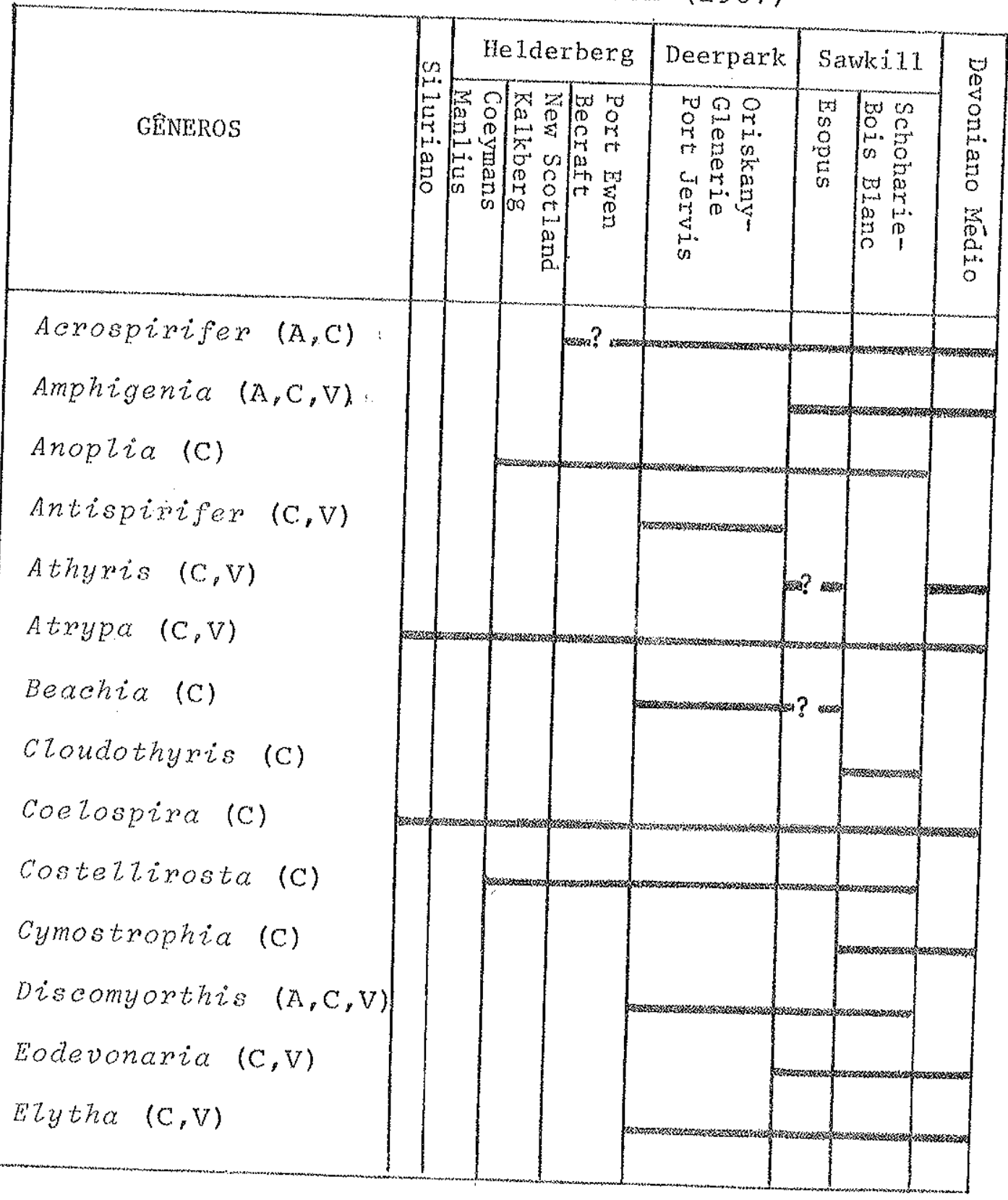




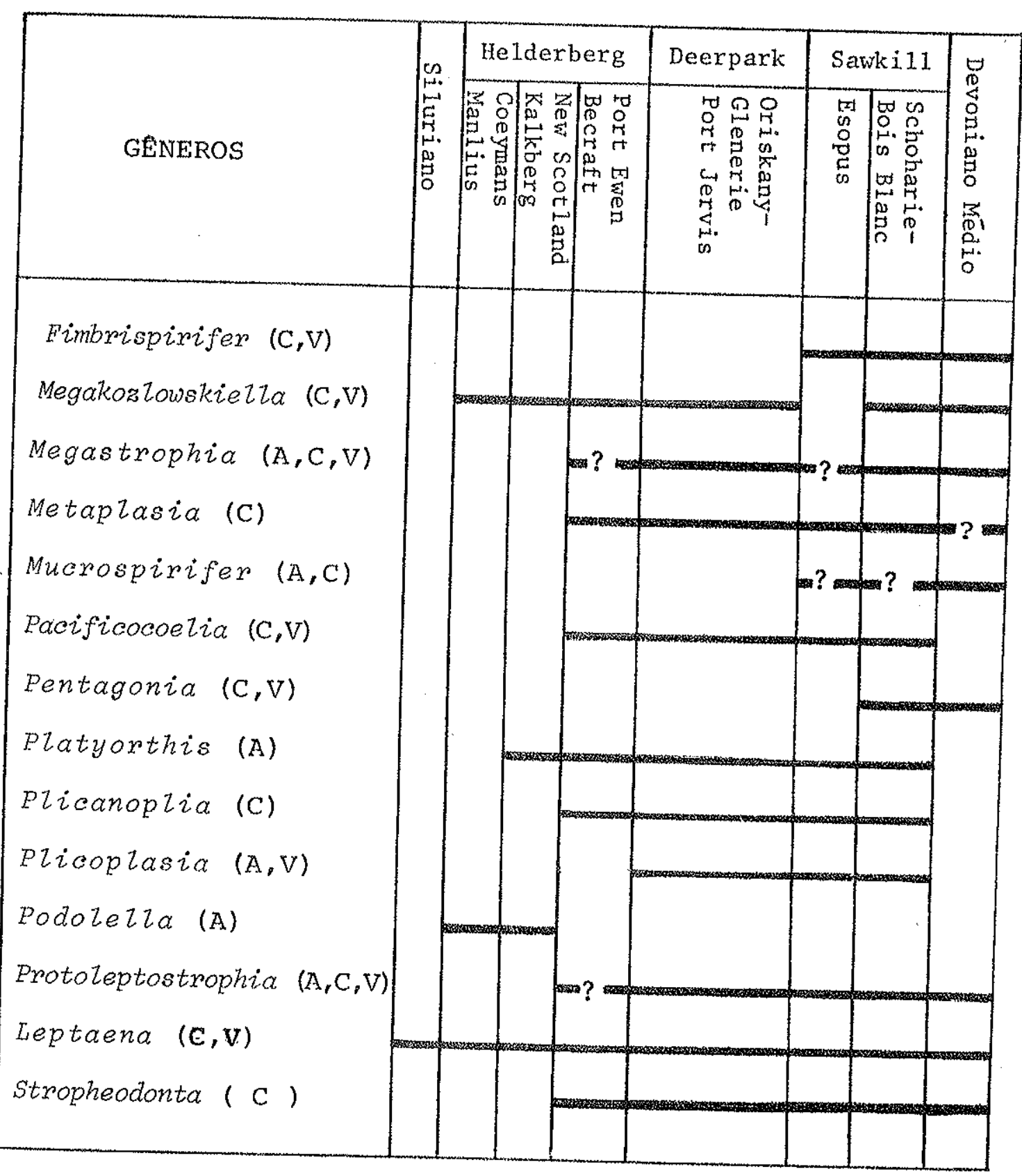
$A=$ Amazônia
$C=$ Colômbia
$\mathrm{V}=$ Venezuela 
APENDICE I

\section{Braquiópodes do Devoniano da Colombia}

\section{Acrospirifer sp.}

- figurada como Acrospirifer colombianus n. sp. in Trapp, D. (1968), p.156, Estampa 3, figs. $11 \mathrm{a}-\mathrm{c}$.

- figurada como Acrospirifer olssoni Caster in Trapp, D. (1968), p.194, Estampa 3, figs.14ae.

- figurada como Acrospirifer venezuelensis(Weis boxd) in Trapp, D. (1.968), p.193, Estampa 3, figs. $2 a-b$.

\section{Acrospirifer atlanticus}

- figurada como Brachyspirifer palmerae Caster n. sp. in Caster,K. (1939), p.164, Estampa 10, figs. 12 e 13; Estampa 12, figs. 5 e 6 . 


\section{Acrospirifer of atlanticus (Clarke) \\ - Eigurada como Acrospirifex atlanticus (Clarke) in Trapp, D. (1968), p. 157, Estampa 3, figs. 12a-d.}

\section{Amphigenia elongata (Vanuxem)}

- Figurada como Amphigenia colombiana n. sp. in Trapp, D。 (1968),p.173,Estampa 2,figs. 8a-E.

\section{Anoplia ?}

- Eigurada como Anoplia nucleata (Ha1l) in Trapp, D. (1.968), Estampa 4, fig. 26.

Antispirifer aff.

- figurada como Acxospixifer olssoni Caster n. sp. in Caster, K. (1939), p.1.56, Estampa 17. figs, 28 e 29, Estmpa 10, figs.15 e 18, Estam pa 11, figs. 10-12; Estampa 12, figs.10-13.

- figurada como Australospirifer cf. antarcticus Caster var. 2 in Caster, K. (1939), p. 163, Estampa 13, Eigs. 19 e 20 . 


\section{Athyris sp.}

- figurada como Athyris spiriferoides (Eaton) in Trapp, D. (1968), p.192,Estampa 2, figs.15a-b

\section{Atrypa reticulares}

- figurada como Atrypa pseudoharrisi n. sp. in Trapp, D. (1968), p.145, Estampa 4, figs.lamb.

- figurada como Atxypa? batensis n. sp. in Trapp, D. (1968), p. 147, Estampa 4, figs.3b-c.

- figurada como Atrypa n. sp. in Trapp, D. (1968), p. 148, Estampa 4, figs.7ame.

- figurada como Atrypa colombiana n. sp. in Trapp, D. (1968), p.144,Estampa 4, figs. 6a-b.

- figurada como Atrypa harrisi Caster n. sp. in Caster, K. (1939), p.140, Estampa 7, figs. 2224: Estampa 10, fig.19, Estampa 11, figs.4 e 5.

- figurada como Atrypa harrisi var. nasuta caster n. var. in Caster, K. (1939), p.142, Estampa 11, figs. $1-3$.

- figurada oomo Dalejina musculosa (Hall) in Trapp D. (1968), p.196, Estampa 4, fig. 14. 
Beachia sp.

- figurada como Beachia colombiana n. sp in Trapp, D. (1968), p. 174, Estampa 2, figs. 2a-d

- figurada como Rensselaria cf. elongata (Conrad) in Trapp, D. (1968), p.191, Estampa 2, fig.3.

Boucotinskis sp.

- figurada como Hedeinina n. gen. colombiana n.sp. in Trapp, D. (1968), p. 160, Estampa 3, figs. $10 a-i$.

\section{Centronella sp.}

- Eigurada como Centronella glansfagea (Hall) in Trapp, D. (1968), p.191, Estampa 2, fig. 5.

- figurada como Centronella sp. in Trapp, D. (1968) p. 177, Estampa 2, fios. loa-b.

\section{Ciougotivyis sp.}

- figurada como Meganteris colombienses n. sp. in Trapp, D. (1968), p.177, Estampa 2, fig. I.

- figurada como Meganteris australis Caster n. sp. in Caster, K. (1939), p. 173, Estampa 9, figs. 25-26; Estampa 13, figs. 9-15. 
- figurada como prionothyris ? colombienses n.sp. in Trapp, D. (1968), p. 175, Estampa 2, figs. $7 a-d$

Davisoniacea sp.

- figurada como Schuchertella arctostriata (Hall) in Trapp, D. (1968), p.196,Estampa 4,figs.17a-b

Discomyorthis musculosa Johnson

- figurada como Dalejina lidalei (Harris \& Wells)

in Trapp, D. (1968),p.195,Estampa, As fig. 10 .

\section{Douvillina?}

- figurada como Douvillina sp. in Trapp,D ( 1968) p. 196, Estampa 4, fig. 18 .

Elytha sp.

- figurada como Elytha colombiana Caster n. sp. in Caster, $K$ (1939), p. 146, Estampa 13, figs. $1-8$. 
Eodevonaria arcuata (Hall)

- figurada como Eodevonaria gjgantea n.sp in Trapp, D. (1968), p.132, Estampa 2, fig.13.

- Eigurada como Eodevonaria transversa (Caster) in Trapp, D. (1968), p.134, Estampa 2, Eigs. $11 a-b$.

- figurada como Eodevonaxia venezuelana (Weisbord) in Trapp, D. (1968), p.133, Estampa 2, figs. $12 \mathrm{a}-i$.

- Eigurada como Eodevonaria imperialis Caster n. sp. in Caster, K.(1939), p.122, Estampa 7, figs. $11-14,17$ e 18; Estampa 9, fig. 3 .

- Eigurada como Eodevonaria imperialis var. parVa Castex n. Var. in Caster, K. (1939), p.126, Estampa 7, fig.9 e 10,15 e 16; Estampa 9,figs. 4-7.

- figurada como Eodevonaria var. transversa Cas tex n. var. in Caster, K. (1939), p.128, Estam pa 7, figs. 5 e 6; Estampa 11, figs.18-20.

- figurada como Eodevonaria reedi Caster n. sp. in Caster,K. (1939), p.129, Estampa 7, fig.4; Estampa 9, figs. 1 e 2 . 
Fimbrispirifer kingi ( Caster)

- figurada como "spirifer kingi Caster n. sp.in Caster, K. (1939), p.15t, Estampa 8, fig. 19; Estampa 10, fig. 14; Estampa 12, figs, 1-4.

Leptaena sp.

- Eigurada como Leptaena boyaca Caster n. sp. in Castex, K. (1939), p.19, Estampa 1, Eigs.4-13; Fistampa 10, figs, $1-3$.

Megastrophia sp.

figurada cono bictyostrophia cooperi caster n. sp. in Caster, $K$. (1939), p.60, Estampa 2,figs. 7-12; Estampa 4, Eig. 9; Estampa 6, Eigs.1-6.

MegakozLowskiella sp.

- figuxada como Australospirifer cE antarticus vax. Caster in Castex, K. (1939), p. 162, Estam pa $12, \mathrm{Figs} .7$ e 8 .

- Eigurada como Kozlowskjeljina andina n. sp. in Trapp, D. (1968), p.161, Estampa 3, fig. 1. 
Netaplasia :

- figurada como Metaplasia pyxidiata (Ha1l) in Trapp, D. (1968), p.195, Estampa 4, figs. 5ad.

Mucrospirifer sp.

- Eigurada como Mediospirifer cundinamarcus n.sp. in Trapp, D. (1968), p.162, Estampa 3, Ejgs. $13 a-b$.

- figurada como Australospirifer cf. antarcticus Caster var. 1. in Caster (1939), p.162, Estampa 13, figs. 21 e 22 .

- figurada oomo Australospirifer ? cE. antarcti. cus Caster var. 2 in Caster, K. (1939), p.163, Estampa 7, fig. 27 .

- figurada como "Spirifer" vaxicosus (Hall) in Trapp, D. (1968), p.193, Estampa 3, fig. 3 .

\section{OR'TOTHETACEA}

- Eigurada como Schellwienella (Schellwienella) goldringae Caster in Trapp, D. (1968), p.191, Estampa 2, fig.4. 
- Eigurada como Schellwienella goldringae Caster n. sp. in Caster, K. (1939), p.116, Estampa 7, figs. 1-3; Estampa 8, figs. 1-2.

- Eigurada como Schellwienella goldringae var.ju vens Caster n. var. in Caster,K. (1939), p.119, Estampa 8, figs. 3-4, 18; Estampa 9, figs.12-24

Pacificocoelia sp.

- Eigurada como Leptocoelia colombiana n.sp. in Trapp. D. (1968), p.150, Estampa 4,figs.12a-b.

- figurada como Leptocoelia n. supsp. nunezi texana Amos \& Boucot in Trapp,D. (1968), Estampa 4, figs. 1la-b-

- figurada como Leptocoelia flabellites (Conrad) in Trapp,D. (1968), p.195, Estampa 4, fig. 2 .

Pentagonia unisulcata

- figurada como Pentagonia colombiana n. sp. in Trapp, D. (1968), p.152, Estampa 2, figs.16a-b.

- figurada como Pentagonia gachala n. sp. in Trapp, D. (1968), p.151, Estampa 2, figs. 19a-b.

- figurada como pentagonia cf. bisulcata (Hall) In Trapp, D. (1968),p.192,Estampa 2,figs.17a-f. 
- figurada como pentagonia gemisulcata Caster in Trapp, D. (1968), p.192, Estampa 2, figs. $18 \mathrm{a}-\mathrm{b}$.

- Eigurada como Pentagonia gemmisulcata Caster n. sp. in Caster K. (1939), p.172, Estampa 10, figs. 16-17.

- figurada como pentagonia casteri n. sp. in Trapp, D. (1968), p.153, Estampa 2,figs.20a-b

- Eigurada como Meristella wheeleri Caster n.sp. in Castex, $\mathrm{K}$ (1939), p.169,Estampa 12, figs. 1.4 e 15 .

Plicanoplia sp.

- figurada como plicodevonaria venezuelana (Weis bord) in Trapp, D. (1968), p.126, Estampa 4, figs. $4 a-j$.

- figurada como Chonetes cf. stubeli Ulrich in Castex, K. (1939),p.131, Estampa 8, figs. 2022 .

- figurada como Chonetes aff. billingsi Clarke in Caster,K. (1939), p.132, Estampa:7, figs. 7 e 8 . 
Plicoplasia sp.

- figurada como Vitulina sp. in Caster,K. (1939) p.142, Estampa 7, figs.30 e 31, Estampa 13, fig. 23 .

\section{PRODUCTACEA}

- figurada como productella cf. spinulicosta Hall em Caster,K. (1939), p.121,Estampa 7,figs.19 e 20 .

\section{Protoleptostrophia sp.}

- figurada como Leptostrophia aff. perplana (Conrad) In Trapp, D. (1968), p.196, Estampa 4,fig. 20 .

- Eigurada como Leptostrophia caribbeana colombiana Caster in Trapp, D. (1968), p.196, Estampa 4, fig. 21 .

- figurada como Leptostrophia oriskania Clarke in Trapp, D. (1968), p.196,Estampa 4, fig.16.

- Eigurada como Rhytistrophia caribbeana var. Colombia Caster n. var. in Caster,k. (1939), p.87, Estampa 5, figs.5-13; Estampa 6, fig.14;Estampa 8, figs. 5-12; Estampa 11, fig. 9. 
Rhynchone11a sp.

- Eigurada como plethorhyncha ? n. sp. in Trapp, D. (1968), p.143, Estampa 2, fig. 6 .

- figurada como Camarotoechia dotis (Hall) in Trapp, D. (1968), p.195,Estampa 4, fig.8.

- Elgurada como Camarotoechia sp. in Caster, $\mathrm{K}$. (1939), p.1.75, Estampa 7, fig. 21 .

Spirifer sp.

- figurada como Atrypa s.1. andina n. sp. in Trapp, D. (1968), p.148, Estampa 4, fig. 13 .

- figurada como "Spirifer" cf. raricosta (Conrad) in Trapp,D. (1968), p.194,Estampa 3,fig. 15.

- figurada como "Spixifer" cf. macrus (Hall) in Trapp, D. (1968), p.193,Estampa 3, fig. 4 .

Spirifer valentianus flart

- figurada como Spinocyrtia ? cf. valenteana Caster in Caster,K. (1939), p.168, Estampa 13, fig. 27 . 
Stropheodonta kozlowskit Caster

- figurada como stropheodonta n. subsp. aff. kozlowskii Caster n. sp. in Trapp,D. (1968),p. 196, Estampa 4 figs. 19a-e.

\section{Stropheodonta sp.}

- figurada como strophonella mexidionalis Caster n. sp. in Caster,K. (1939), p.107, Estampa 4, fig. 3.0; Estampa 8, figs. 16 e 17 .

STROPHEODONTIDAE ?

- figurada como Stropheodonta (Stropheodonta) n. sp. in Trapp, D. (1968), p.119, Estampa 4, fig. 25 .

- figurada como Stropheodonta sp. in Caster, $K$. (1939), p.70, Estampa 10, Ejgs. 7 e 8 .

\section{Strophonella?}

- figurada como Strophonella floweri Caster n. sp. in caster,K. (1939), p.109, Estampa 2, figs. 2 e 3; Estampa 10, figs. 9-11. 
APENDICE II

\section{Braquiópodes do Devoniano da Venezuela}

\section{Amphigenia elongata (Vanuxem)}

- figurada como Amphigenia elongata var. Weisbord n. var. In Liddle, Harris \& Wells, Bulletin of American Paleontology 1943, V.27, N.108, p.65, Estampa 6, Eigs. 12-16.

\section{Antispirifer sp.}

- figurada como spirifer olssoni caster in Liddle, Haxris \& Wells, Bulletin of American Pa leontology 1943, V.27, N.108, p.68,Estampa 7, fig. 5 .

\section{Atrypa "reticularis"}

- figurada como Atrypa reticularis var. harrisi Caster in Liddle, Harris \& Wells, Bulletin of American Paleontology 1943,V.27,N.108,p.66, Es tampa 6 , fig, 18 . 


\section{Athyris sp.}

- figurada como Athyris spiriferoides (Eaton) in Liddle, Harris \& Wells, Bulletin of Amer1 can Paleontology 1943, V.27, N.108, p.70, Es tampa 7 ; fig. 10 .

Discomyorthis musculosa Johnson

- figurada como Rhipidomella lidalei n. sp." in Liddle, Harris \& Wells, Bulletin of American Paleontology 1943, V.27, N.108,p.56,Estampa 4, figs. $1-3$ e $3 a$.

\section{Elytha sp.}

- figurada como Elytha ? plana n. sp. In Liddle, Harris \& Wells, Bulletin of American Paleonto logy 1943, V.27, N.108,p.69,Estampa 7, Eig.6.

- figurada como Elytha colombiana Caster in Lid dle, Harris \& Wells, Bulletin of American Pa leontology 1943, V.27, N.108, p. 69, Estampa 7, fig. 7 . 
Eodevonaria arcuata (Hall)

- Eigurada como Chonetes (Eodevonaria) subhemisferica Weibord in Liddle, Harris \& Wells, Bul letin of American Paleontology 1.943,V.27, N.108, p. 61, Estampa 5, figs. 7-9; Estampa 6, figs. $1-4$.

- figurada como Chonetes venezuelensis Weisbord in Liddle, Harris \& Wells, Bulletin of American Paleontology 1943, V. 27, N. 108, Estam pa 6, figs. 5-6 e 6a.

- figurada como "Eodevonaria imperialis ? Caster in Liddle, Harris \& Wells, Bulletin of Amexi can Paleontology 1943, V.27,N.1.08,p.63, Estampa 6, fig. 8 .

\section{Fimbrispirifer kingi (Caster)}

- figurada como spirifer kingi Caster in Liddle, Harris \& Wells, Bulletin of American Paleonto logy 1943, V. 27, N. 108, p.68, Estampa 7,figs. $2-4$. 
Leptaena sp.

- figurada como Leptaena rhomboidalis (Wilckens) in Liddle, Harris \& Wells, Bulletin of Ameri can Paleontology 1943, V. 27, N. 108, p. 57, Estampa 4, fig. 4 .

Megastrophia sp.

- figurada como Dictyostrophia cooperi Caster in Liddle, Harris \& Wells, Bulletin of American Paleontology 1943, V. 27, N. 108, p. 58,Estam pa 4 , figs. 10-13.

ORTOTHETACEA

- figurada como Schellwienella goldringae Caster in Liddle, Harris \& Wells, Bulletin of Ameri

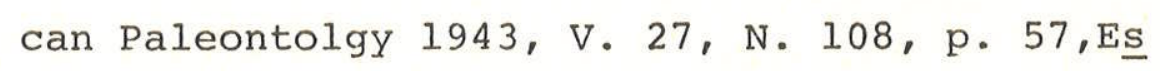
tampa 4, figs. 7-8 e 8a.

\section{Pacificocoelia}

- Leptocoelia nunezi taxana Amos \& Boucot, infor mação verbel de Boucot, A.J., em 1971 . 


\section{Pentagonia unisulcata}

- figurada como Pentagonia ? gemmisulcata Castex in Liddle, Harris \& Wells, Bulletin of AmeriCan Paleontology 1943, V. 27, N. 108, p.71, ES tampa 7, fig. 11 .

- figurada como Mexistella wheeleri Caster, in Liddle, Harris \& Wells, Bulletin of American Paleontology 1943, V. 27, N. 108, p. 70, Estam pa 7 , figs. 8 e 9 .

\section{Plicanoplia}

- figurada como Chonetes stubeli Ulrich in Iiddle, Harris \& Wells, Bulletin of American Pale ontology 1943, V. 27, N. 108, p. 62, Estampa 6, fig. 7 .

\section{Protoleptostrophia}

- figurada como Leptostrophia concina (Morris \& Sharpe, in Liddle, Harris \& Wells, Bulletin of American Paleontology 1943, V. 27, N.108,p. 57, Estampa 4, Eig. 6 . 
- Eigurada como Leptostrophia caribbeana Weis bord in Liddle, Harris \& Wells, Bulletin of American Paleontology 1943, V. 27, N. 108, p. 57, Estampa 4, fig. 9 .

Rhynchone11a sp.

- figurada como Camarotoechia sp. in Liddle, Har ris \& Wells, Bulletin of American Paleontolo gy 1943, V. 27, N. 108, p. 63, Estampa 6,fig. 17 .

Salopina sp.

- figurada como Dalmanella cf. nettoana Rathbun in Liddle, Harris \& Wells, Bulletin of Ameri can Paleontology 1943, V. 27, N. 108, p. 56, Estampa 4, fig. 5 . 
S $\forall$ d W $W$ U S I 


\section{ESTAMPA}

\section{Legenda}

Derbyina jamesiana (Rathbun)

Figs. 1 e 2 - Reproduções de ilustrações mostrando - interior das valvas (1) ventral e (2) dorsal; X 2. Segundo Dexby, O.A. (1896).

Valva ventral mostrando o sulco mediano:

Fig. $3 \times 2,5$ MN 01; Fig. $4 \times 2,5$ MN 02; Fig. $5 \times 2,7$ MN 03; Fig. $9 \times 2,2 \mathrm{MN} 04 ; \mathrm{Fig} .10 \times 2,6 \mathrm{MN} 05$; Fig. $11 \times 2,6 \mathrm{MN} 06$.

Molde de látex da valva ventral:

Fig. $6 \times 2,5$

Valva dorsal: Fig. $7 \times 2,5 \mathrm{MN} 07$

\section{Paranaia waxdiana (Rathbun)}

Figs. 12 e 13 - Reprodução de ilustrações mostrando o interior das valvas (12) dorsale (13) ventral de Paranaia, x 2. Segun do Dexby O.A. (1896). 
Fig. 14 - Valva dorsal X 2,5 MN 08 .

Fig. 15 - Vista da valva ventral X 2,7 MN 09.

Podole11a derbyana (Hartt)

Fig. 16 - Molde externo da valva dorsal X 2,7 MN 10.

Fig. 17 - Molde externo da valva ventral X 2,7, MN 10.

Fig. 18 - Molde de lätex da valva dorsal $x 2,7$, MN 10.

Plicoplasia curupira (Rathbun)

Fig. 19 - MN 3516, X 3 Molde látex da valva ven tral.

Fig. 20 - Molde de Iâtex da valva dorsal x 2, MN 11.

Fig. 21 - Molde de lätex da valva dorsal x 1,5 MN 3516 .

Fig. 22 - Molde de lätex da valva ventral x 1,7 MN 12 . 
Fig. 23 - Molde de látex da valva dorsal mostrando fossetas dentárias, X 1,8 MN $3520 \mathrm{I}$

Fig. 24 - Molde de lätex da valva dorsal X 1,7 MN 13.

Fig. 25 - Molde de Iātex da valva dorsal mostrando parte do processo cardinal e fos setas dentärias $\times 3,2$ MN 14 .

Fig. 26 - Molde de látex da valva ventral x 2,2 MN 15.

Fig. 27 - Molde de lätex da valva ventral X 2,4 MN 16. 
R. G. DE CARVALHO

ESTAMPA 1

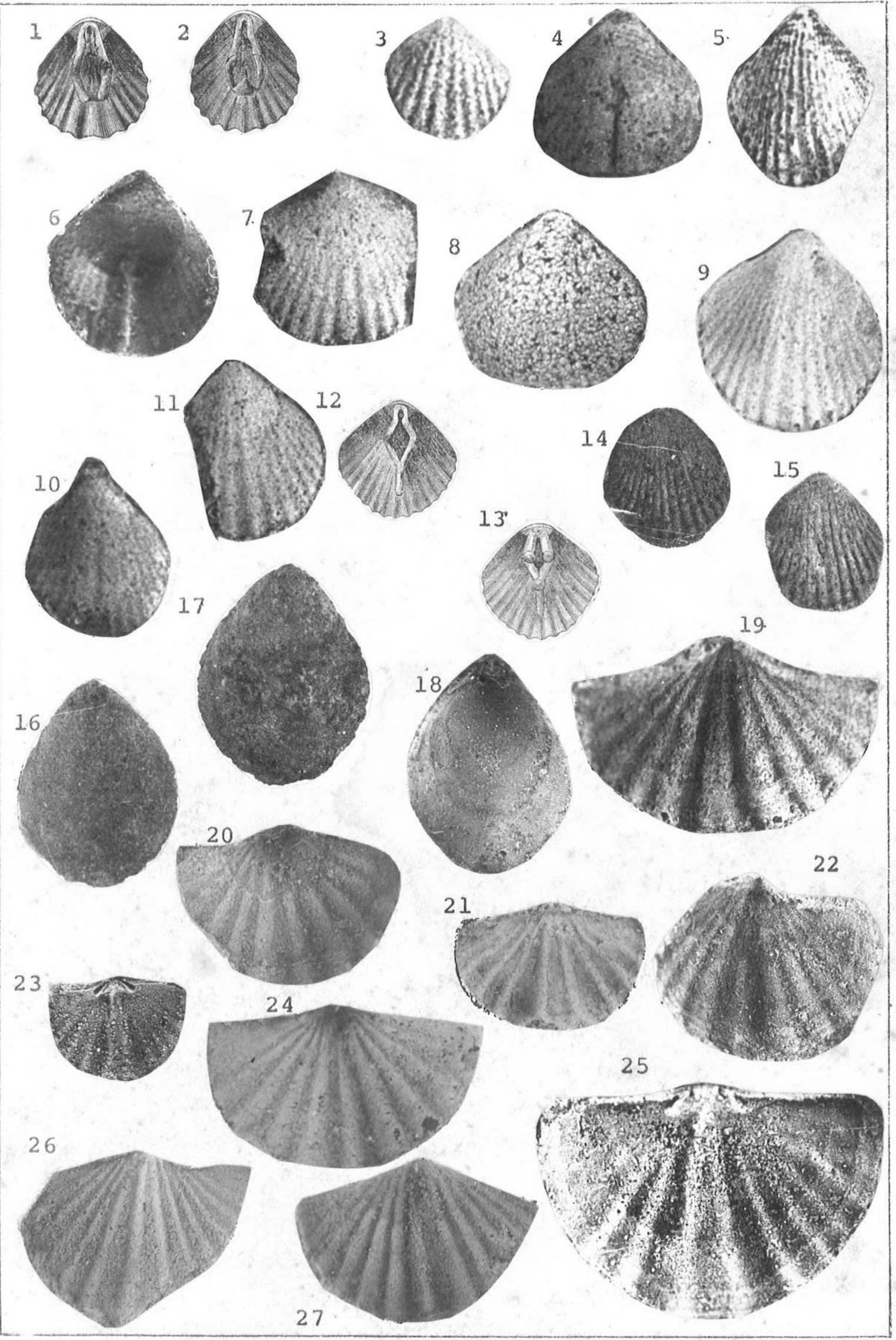


ESTAMPA 2

\section{Legenda}

Tropidoleptus carinatus (Conrad)

Fig. 1 - Molde de látex da valva dorsal $\times 1,5$ MN 17.

Fig. 2 - Molde de látex da valva ventral $x 1,2$ MN 18 .

Fig. 3 - Molde de látex da valva ventral apresentando linhas de crescimento $\times 1,4, \mathrm{MN} 19$.

Fig. 4 - Molde de lätex da valva ventral $\times 1,7$ MN 20 .

Fig. 5 - Molde de lätex da valva dorsal $\times 1,2$ MN 21.

Fig. 6 - Molde de lätex da valva dorsal x 1,2 MN 22 .

Fig. 7 - Molde de lätex da valva ventral $x 1,7$ MN 23.

Fig. 8 - Molde de látex da valva dorsal x 1,2 MN 24 . 
Fig. 9 - Molde de látex da valva dorsal x 2 MN 25.

Fig. 10 - Molde de látex da valva dorsal x 1,8 MN 26 .

Fig. 11 - Molde de lätex da valva dorsal x 2 MN 27.

Fig. 12 - Molde de látex da valva dorsal x 2 MN 28.

Fig. 13 - Molde de lätex da valva ventral apresentando a interärea com linhas de cresci mento paralela ã linha cardinal, x 2,2 MN 29.

Fig. 14 - Molde de lätex da valva ventral apresentando dentes e deltirio aberto, $\times 2$ MN 30 . 


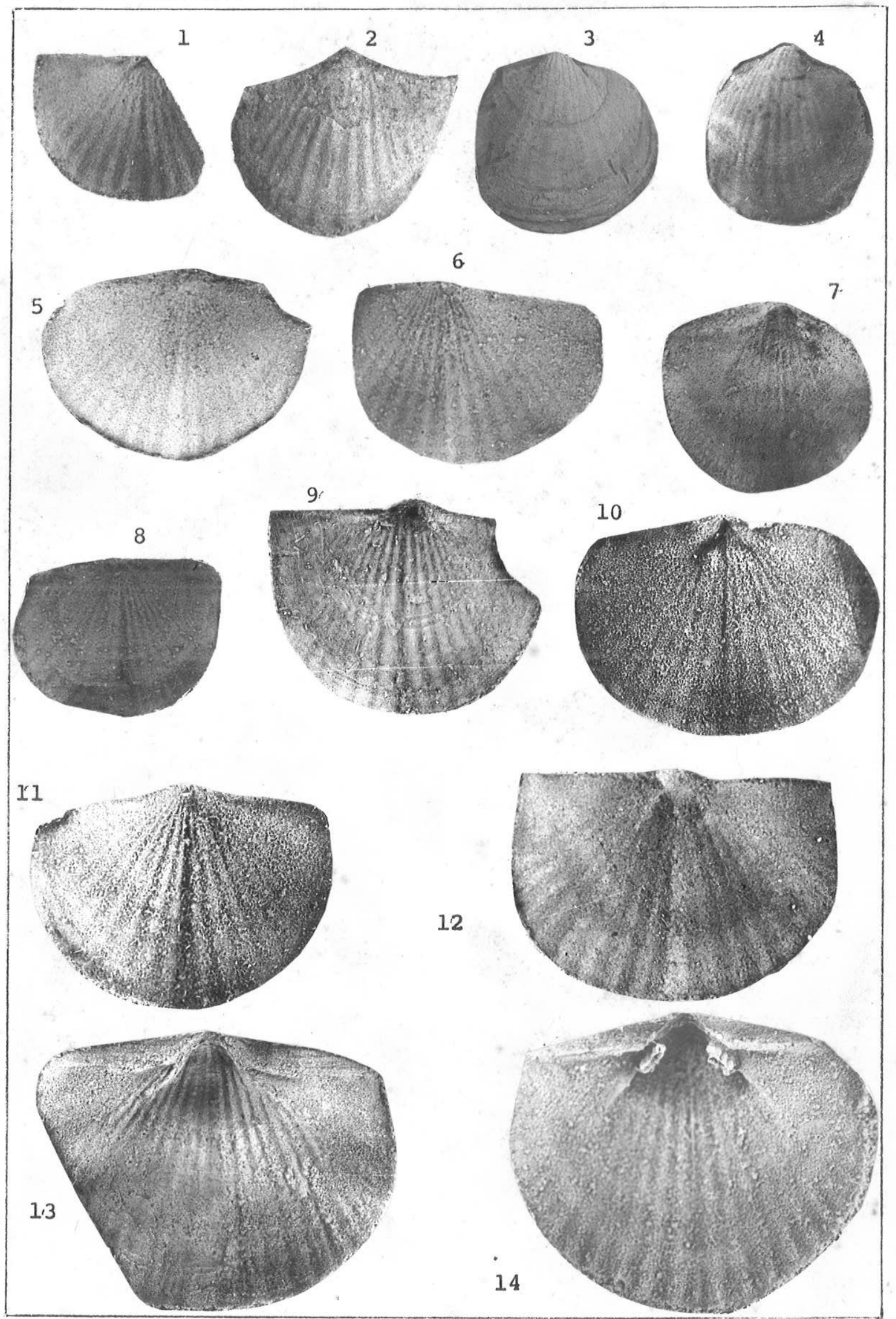


ESTAMPA 3

\section{Legenda}

\section{Tropidoleptus carinatus (Conxad)}

Fig. 1 - Molde de Lätex da valva ventral X 1,8 MN 31 。

Fig. 2 - Molde de lätex da valva dorsal X 1,5 MN 32 。

Fig. 3 Molde de lácex da valva dorsal $x$ 2,1 MN 33.

Fig. 4 - Molde de lätex da valva dorsal apresentando linhas de crescimento lamelosas subconcêntricas, X 1,5, MN 34 .

\section{Amphigenia elongata (Vanuxem)}

Fig. 5 - Valva dorsal X 1, MN 35.

Fig. 6 - Valva dorsal X 1, MN 36, apresentando linhas de crescimento subconcêntricas circulares a elipsoidais. 
Fig. 7 - Valva ventral X 1, MN 37, apresentando impressōes deixadas pelo espondilium e linhas de crescimento.

Fig. 8 - Valva ventral. $\times 1, \mathrm{MN} 38$, apresentando linhas de crescimento. 
R. G. DE CARVALHO

ESTAMPA 3

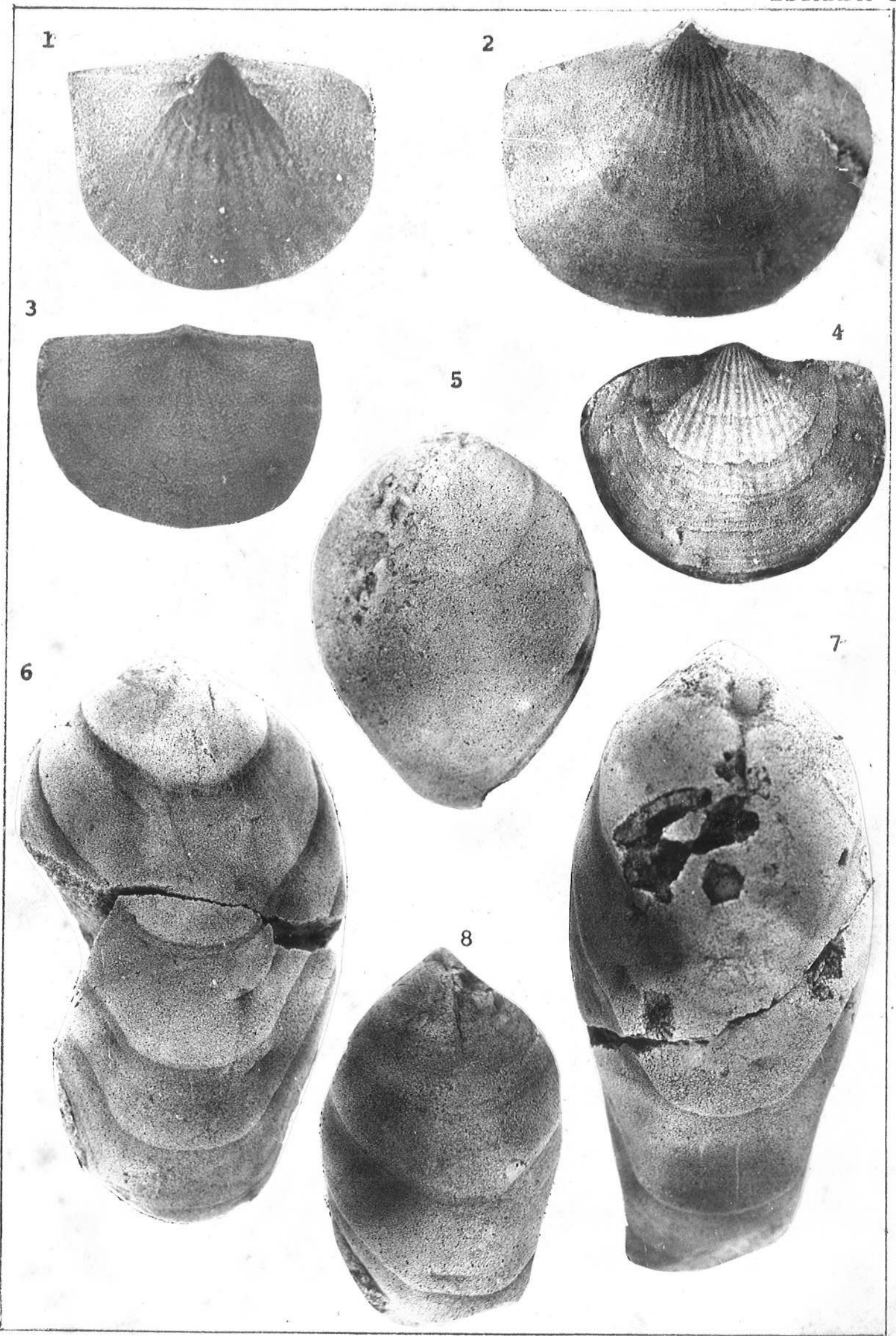




\section{ESTAMPA 4}

\section{Legenda}

\section{Discomyorthis hartti (Rathbun)}

Fig. 1 - Molde de lätex da valva dorsal mostran do costelas, processo cardinal, placas do braquióforo, fossetas dentärias e miofragma $x 2, \mathrm{MN} 31$.

Fig. 2 - Molde de látex da valva ventral mostrando a ärea muscular flabeliforme e miofragmas, $\mathrm{X} 2,1, \mathrm{MN} 32$.

Fig. 4 - Molde interno da valva dorsal $\mathrm{x} 2,1$, MN 31.

\section{Platyorthis nettoanus (Rathbun)}

Fig. 3 - Molde de Iátex da valva dorsal mostran do caracteres internos: processo cardinal, miofragma, processos crurais e fossetas dentärias, X 3, MN 32 .

Fig. 5 - Molde de lätex da valva ventral mostrando o deltírio e contorno da ārea muscu $\operatorname{lar} \times 3,5, \mathrm{MN} 33$. 
Protoleptostrophia sp.

Fig. 6 - Molde de lātex da valva ventral x 2,6 MN 34 .

Fig. 7 - Molde de lätex da valva ventral $x$, MN 35.

Fig. 8 - Molde de lätex da valva ventral $\times 1,5$ MN 36, apresentando a ărea muscular estria da longitudinalmente por miofragmas. 


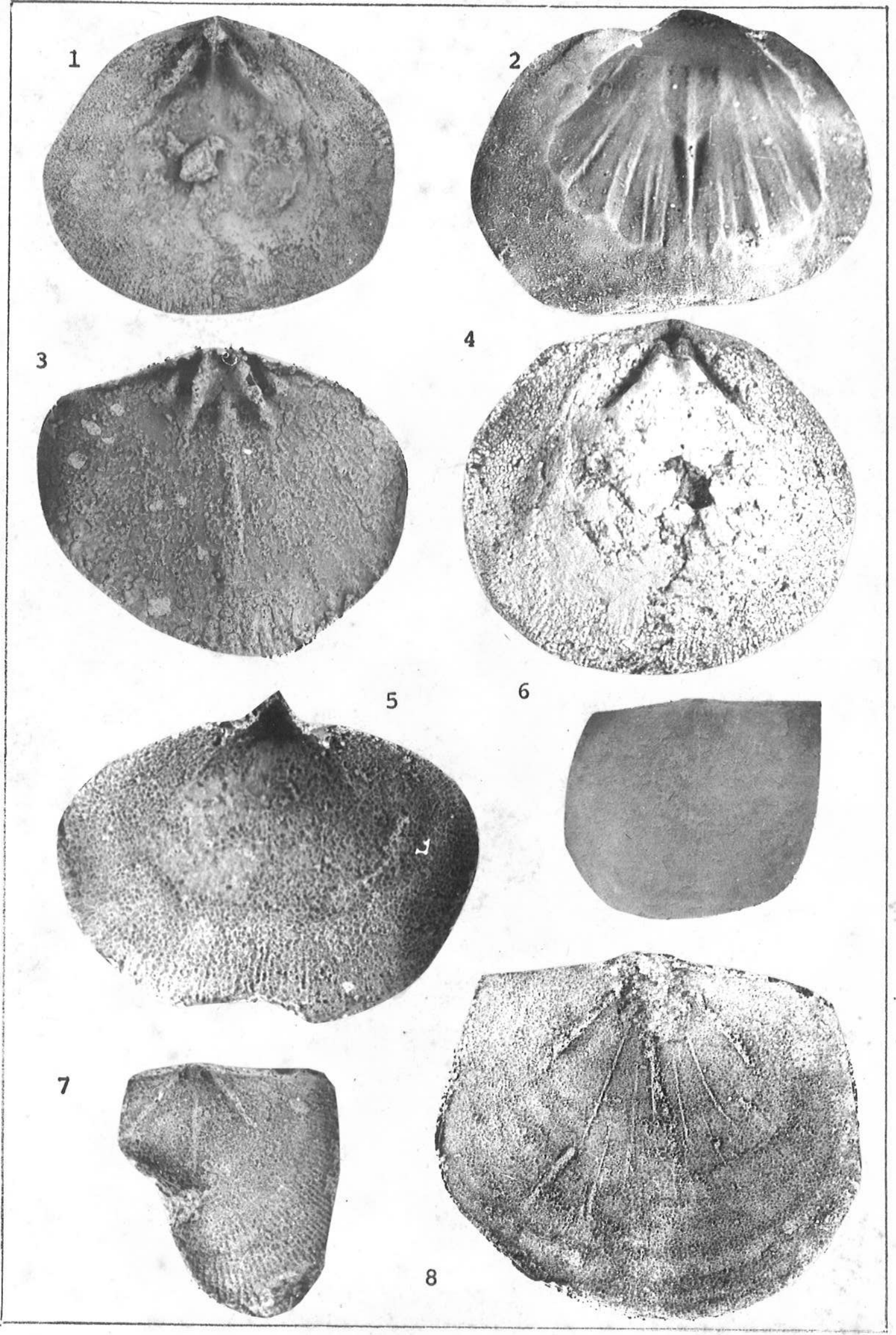


ESTAMPA 5

\section{Legenda}

Protoleptostrophia sp.

Fig. 1 - Molde de lätex da valva ventral com ārea muscular estriada, X 1,3 MN 37.

Acrospirifer duodenarius (Hall)

Fig. 2 - Molde da valva dorsal $\times 1,3$ MN 38.

Fig. 5 - Molde de látex da valva ventral x 2, 1 MN 39, mostrando deltírio aberto, dentes, miofragma e área muscular lanceolar.

Megastrophia hoeferi (Katzer)

Fig. 3 - Molde interno da valva dorsal apresentando impressões dos músculos adutores separadas pelo miofragma; processo cardinal, fossetas dentárias e linha cardinal denticulada, $\mathrm{x} 2,2$ MN 40 . 
Fig. 4 - Molde de lätex da valva ventral apresentando áxea muscular e miofragmas $\times 2,5$ MN 41 . 
R. G. DE CARVALHO

ESTAMPA 5

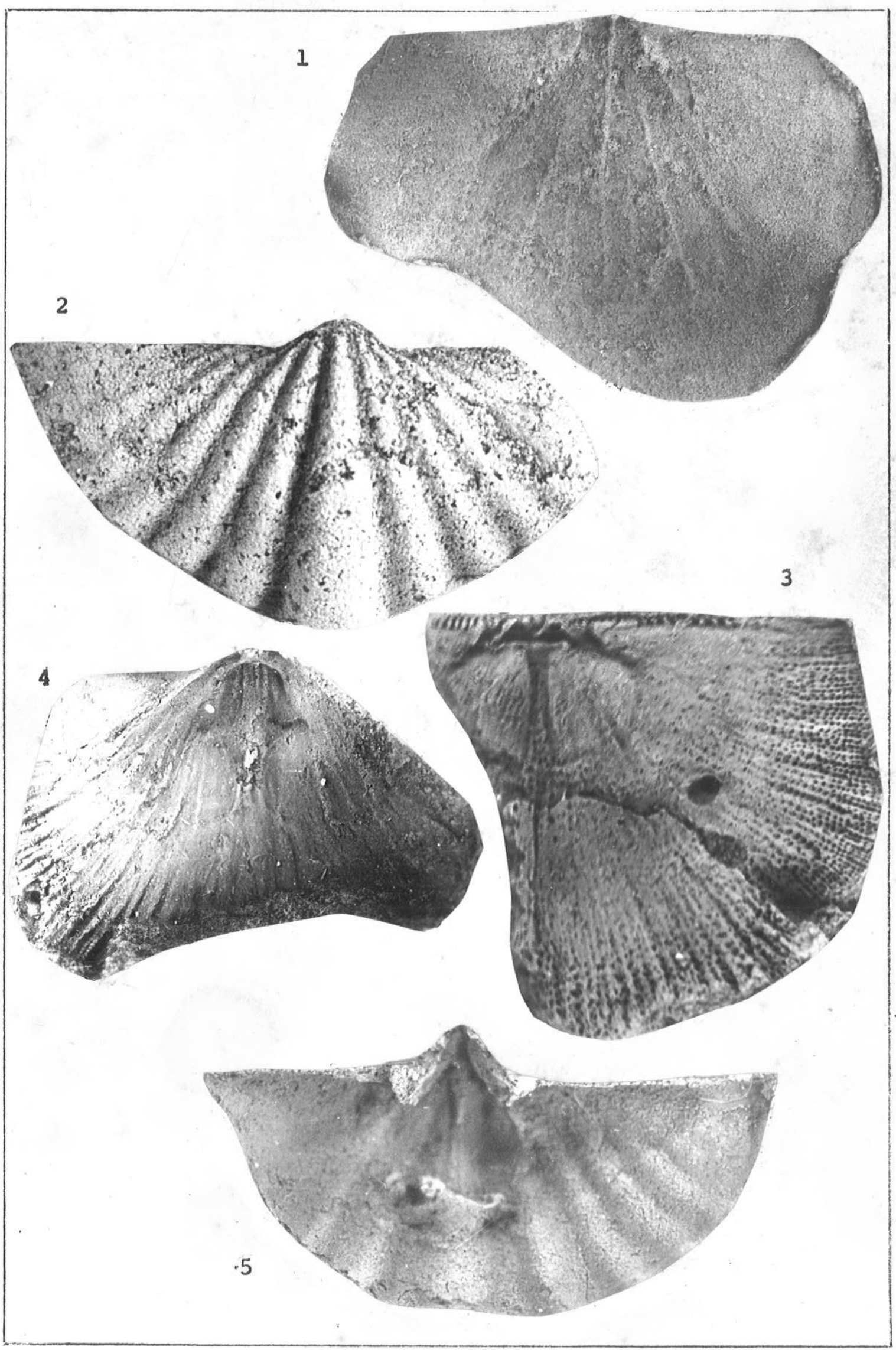


ESTAMPA 6

\section{Legenda}

\section{Acrospirifer buarguianus (Rathbun)}

Fig. 1 - Molde de lätex da valva ventral apresentando a interärea, deltixio; $\times 1,8$ MG 42 .

Fig. 2 - Molde de lätex da valva ventral apresentando ärea muscular lanceolar, X 1,8 MG 43 .

Fig. 3 - Molde de látex da valva dorsal apresentando lamelas subconcêntricas, X 1,3 MG 44 。

Fig. 5 - Molde de lātex da valva ventral x 1,8 MG 45 .

\section{Mucrospirifex pedroanus (Haxtt)}

Fig. 4, 7 e 9 - Molde de lätex da valva ventral apre sentando Iinhas de crescimento lamelosas subconcêntricas bem distintas na figura 9. $\mathrm{X} 1,7$ MN $46 ; \times 2$ MN $47 ; \mathrm{X} 1,8$ MN 48 。 
Figs. 6 e 8 - Molde de látex da valva dorsal apresentando linhas de crescimento.X 1,2 MN 49; $\times 1,4$ MN 50 . 


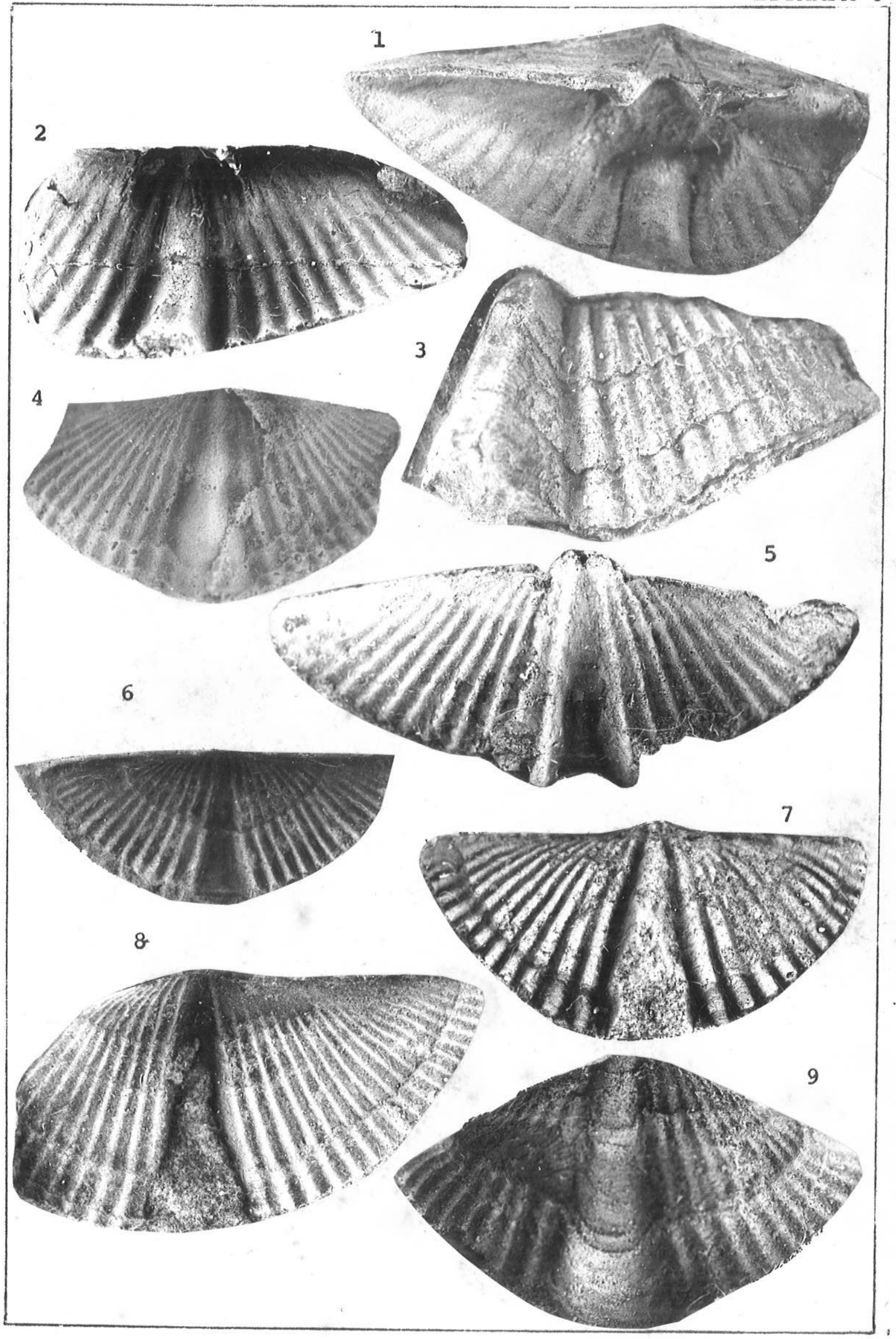


ESTAMPA 7

\section{Legenda}

\section{Mucrospirifer pedroanus (Hartt)}

Fig. 1 - Molde de lätex da valva dorsal apresentando linhas de crescimento X 2 MN 51.

Rhynchonella ? sp. A

Figs. 2, 3, 4, 6 e 7 -Valvasdorsais, X 1,5 MN 52;

$\mathrm{X} 1,5$ MN $53 ; \mathrm{X} 1,5$ MN $54 ; \mathrm{X} 1,5 \mathrm{MN} 55 \mathrm{e}$ $\times 1,5$ MN 56 .

Figs. 5 e 8 - Valvas ventrais, X 1,5 MN 57 e X 1,5 MN 58 .

Rhynchonel la sp. B

Fig. 10 - Valva dorsal e vista de sua dobra. $\times 1,3 \quad \mathrm{MN} 59$.

Fig. 11 - Valva ventral $\mathrm{x} 1,3 \mathrm{MN} 60$. 
Rhynchonella ererensis Rathbun
Fig. 9 - Vista anterior da valva dorsal $\times 1,2$ MN 3509-T.

Fig. 12 - Molde externo da valva dorsal x 1,2 MN 3509-I.

Eig. 13 - Valva dorsal X 1,2 MN 3509-I.

Fig. 14 - Valva dorsal X 1,2 MN 3509-I. 


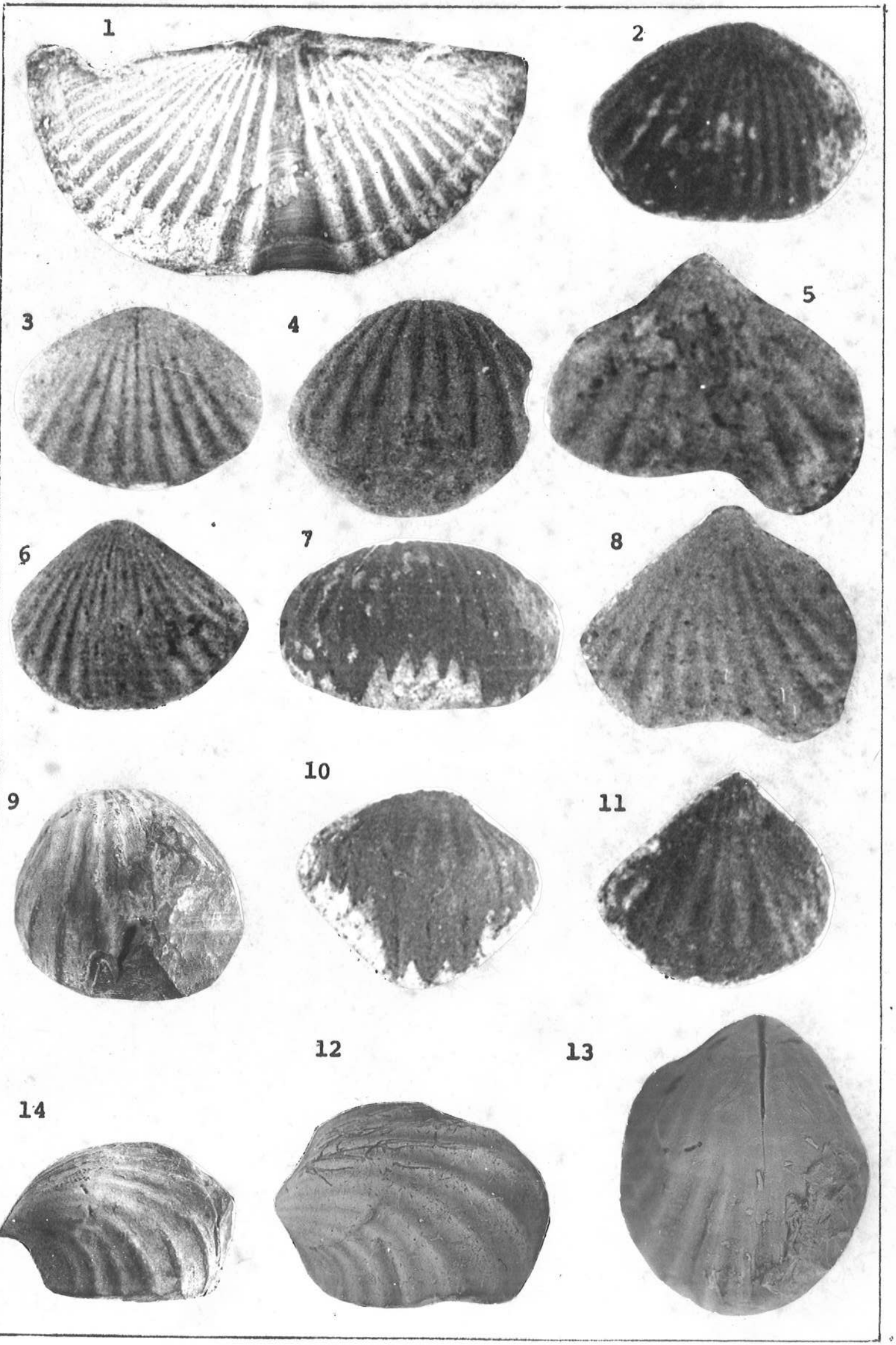


ESTAMPA 8

\section{Legenda}

\section{Chonetes freitasi Rathbun}

Figs. 1 e 2 - Moldes de lātex das valvas ventrais.

$$
X 1,2 \text { MN } 61 ; \times 1,3 \text { MN } 62 \text { 。 }
$$

\section{Chonetes onettianus Rathbun}

Fig. 3 - Molde de látex da valva ventral apresentando um septo pequeno e fino $\times 2$ MN 63 。

\section{Chonetes comstocki Hartt}

Fig. 4 - Molde de lätex da valva ventral $\times 2$ MN $3432-I$.

Streptorhynchus agassiz1 Hartt

Figs. 5 a 12 - Moldes de látex de valvas ventrais $\mathrm{X}$ aprox. 2,5 . 


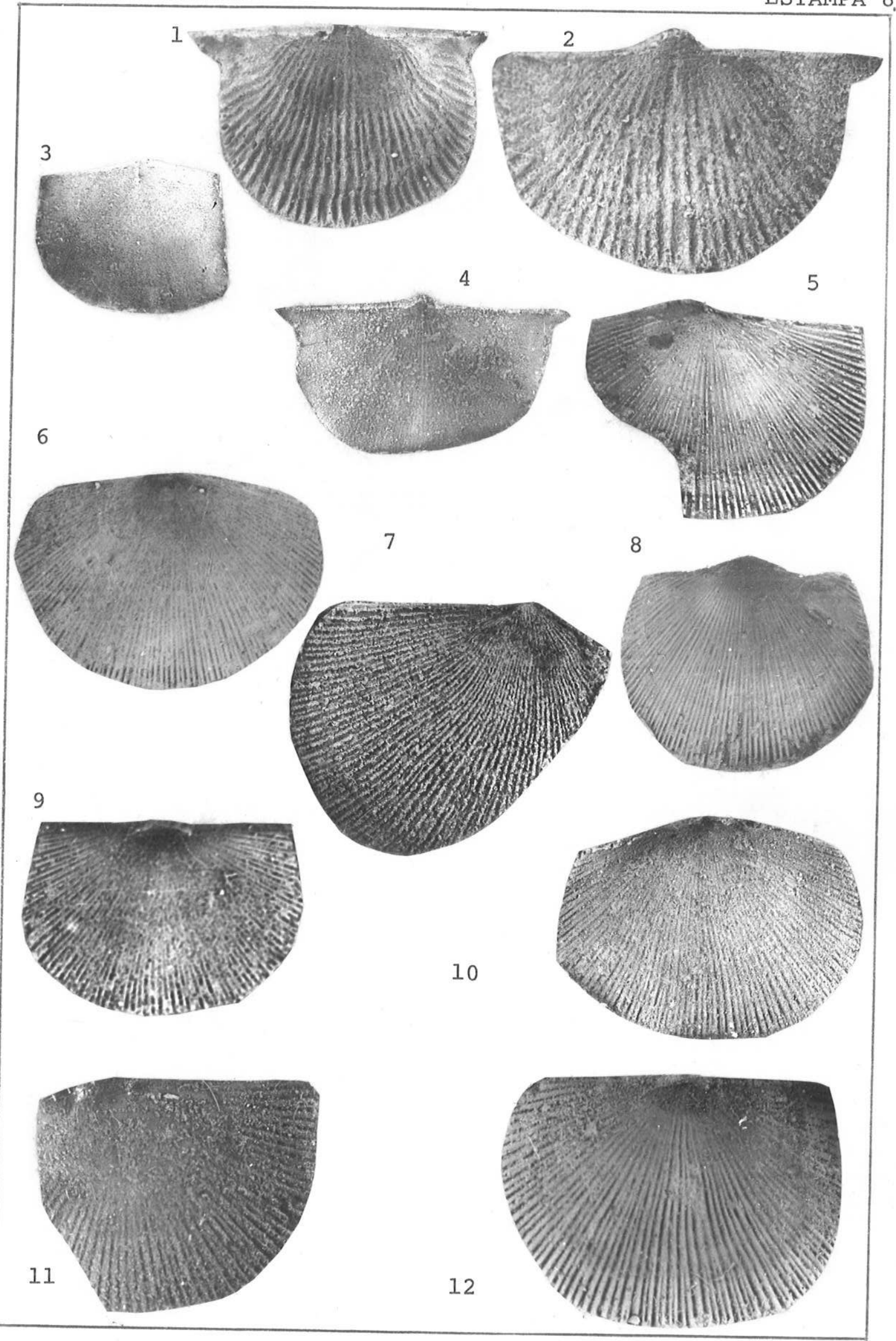




\section{BIBL IOGRAF IA}

AMOS, A. \& BOUCOT, A.J., 1963: A revision of the brachiopod family Leptocoeliidae, Palaentology, V. 6, Paxt 3, Palaeontological Association, London.

ANDERSON, M.M., BOUCOT, A.J. \& JOHNSON, J.G., 1969: Eifelian brachiopods from Padaukpin, Nor thern Shan States, Burma; Bulletin of the Britsh Museum (Natural History) Geology, V. 18, N. 4, pp. 108-163, London.

ASSELBERGHS, E., 1946: L'Eodevonien de I'Ardenne et des Rëgions voisines, Mëmoires de L'Institut Gëologique de L'Université de Louvain, Tome XIV, Louvain.

BOUCOT, A.J., 1957: Revision of some Silurian and Early Devonian Spiriferid Genera and Erection of Kozlowskiellinae, New subfamily, Senckenbergiana Lethaea, Band 38 , N. 5/6, pp. 311-334, Frankfurt. 


\begin{abstract}
BOUCOT, A.J., 1959: Brachiopods of the Lowex Devo nian rocks at Higland Milis, New York, Journal of Paleontology, V. 33, N.5, pp. 727-769, USA.
\end{abstract}

BOUCOT, A.J., 1960: Lower Gedinnian Brachiopods of Belgium, Mëmoires de I'Institut Gëolom gique de L'Université de Louvain, , Tome XXI, pp. 283-324, Louvain.

BOUCOT, A.J..\& AMSDEN, T.W., 1958: Stratigraphy and Paleontology of the Hunton Group in the Arbukle Mountain Region, Part IV: New Ge nera of Brachiopods, Oklahoma Geological Survey, Bulletin 78, pp.159-199, USA.

BOUCOT, A.J. \& ARNDT, R., 1960: Fossils of the Littleton Formation (Lower Devonian) of New Hampshire, Geological Survey Profes sional Paper 334-B, pp.41-51, Washington, USA.

BOUCOT,A.J., GAURI,K.L. \& SOUTHARD,J.,1970: Siluri an and Lower Devonian Brachiopods, struc ture and stratigraphy of the Green and Outlier in Southeastern New York, Palae 
ontographica, Beitrage zur Naturgeschich te der Vorzeit, Band 135. Abt. A, stutt gart E. Schweizerbart'sche Verlagsbuch handlung (Nagele $u$. Obermiller).

BOUCOT, A.J. \& GILL, E.D., 1956: Australocoelia, a new Lower Devonian brachiopod from Sou th Africa, South America, and Australia, Journal of Paleontology, v. 30, N.5, pp. $1173-1178$, USA.

BOUCOT, A.J. \& HARPER, C.W., 1968: Silurian to Lower Devonian Chonetacea, Journal of Paleonto logy, V. 42, N. 1, pp. 143-176, USA.

BOUCOT, A.J. \& JOHNSON, J.G., 1967: Paleogeography and correlation of Apalachian province Lowex Devonian Sedimentary rocks, Tulsa Geological society Digest, $V .3$, sympo sium volume: "Silurian-Devonian rocks of Oklahoma and Environs", USA.

BOUCOT, A.J. \& JOHNSON, J.G., 1968: Brachiopods of the Bois Blane Formation in New York, Geo 
logical Survey Professional Paper 584-B, pp. B $1-B$ 27, Washington, USA.

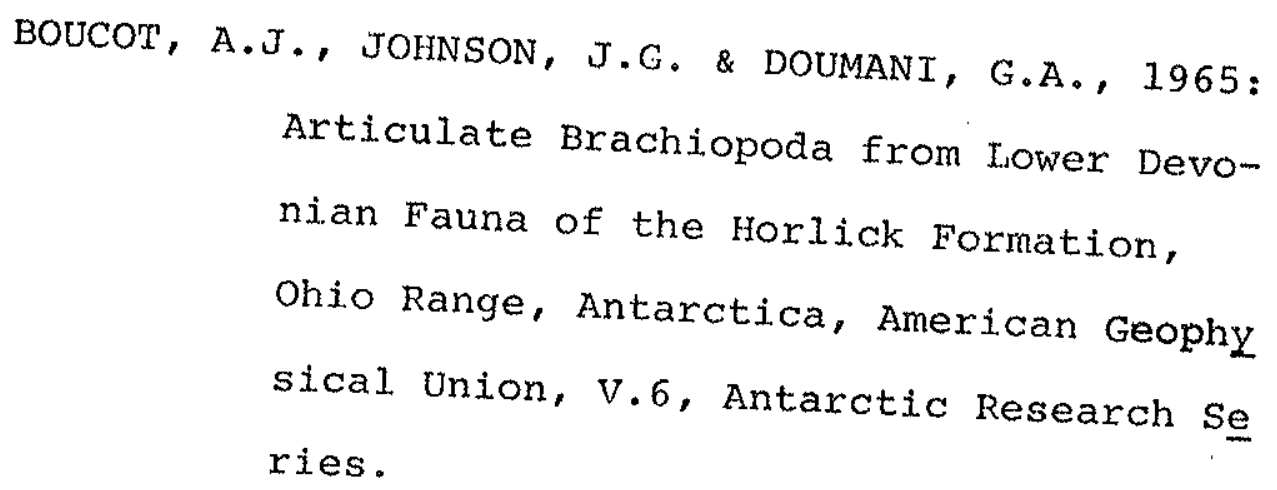

BOUCOT, A.J., JOHNSON. J.G. \& TALENT, J.A., 1969: Early Devonian Brachiopod Zoogeography, Geological Socjety of America, Special Paper 119, Boulder, Colorado, USA.

BOUCOT, A.J., JOHNSON. J.G. \& WALMSLEY, V.G., 1965 : Revision of the Rhipidomellidae (Brachi opoda) and the affinities of Mendacella and Dalejina, Journal of Paleontology , V. 39, N. 3, USA.

BOUCOT, A.J., MARTINSSON, A. THORSTEINSSON, R., WALLISER; O.H., WHITTINGTON,H.B. \& YOCHELSON, E. , i. 
1959: A Late Siluxian Fauna from Suthex land River Formation, Devon Island, $\mathrm{C}$ a nadian Arctic Archipelago, Geological Survey of Canada, Bulletin 65, Department of Mines and Techinical Surveys, Canada.

BRANISA, I., 1965: Los fosiles guias de Bolivia, I. Paleozoico, Servicio Geologico de Boli via, Boletin N.6, La Paz, Bolivia.

CASTER, K.E., 1939: A Devonian Fauna from Colombia, Bulletins of American paleontology, $V$. 24, N.83, Ithaca, New York, USA.

CASTER, K.E., 1942: The age and relations of colom bian Devonian strata. proceedings of the Eighth American Scientific Congress. 1940, V.IV, Geological Sciences,pp.27-28, USA.

CLARKE, J.M., 1900: The paleozoic Faunas of Para, Brazil, 2. The Devonian Mollusca of the 
State of Para (Archivos do Museu Nacio nal do Rio de Janeiro, v.10, 1899).

CLARKE, J.M., 1913: Fösseis Devonianos do paranä, Serviço Geolögico e Mineralögico do Brạ sil, Rio de Janeiro, Brasil.

CLARKE, J.M., 1913: Ninth report of the director of the Science Division, New York State Mu seum, Museum Bulletin 164, University of the state of New York Bulletin, AIbany, N.Y., USA.

CLOUD JR., P.E., 1942: Terebratuloid Brachiopoda of the Silurian and Devonian, Geological Society of America, Special papers, N. 38, USA.

DERBY, O.A., 1896: Notas sobre a Geologia e Paleontologia de Matto Grosso: Rio de Jane ro, Mus. Nac., Archivos V. IX, p. 5988, Rio de Janeiro, Brasil. 
GRABAU, A.W., 1913: Guide to the Geology and paleon tology of the Schoharie valley in Eas tern New York, New York state Museum, Pa teontology 13, Bulletin 13, USA.

GRABAU, A.W., 1931: Studies for students, series I, Paleontology, The Brachiopoda, Part.2, Reprtnted from the Science Quartely of the National University of Peking, V.II, PP. 397-422, USA.

HALL, J., 1859: Palaeontology, Geological Survey of New York, V. IIJ, 1.855-1859, Part I:Text, Albany, N.Y., USA.

HALL, J., 186I: Palaeontology, Geological Survey of New York, V. III, 1855-1859, Paxt I: PIa tes, Albany, N.Y., USA.

HALI, J., 1867: Palaeontology, Geological Survey of New York, V. IV, Part I, 1862-1866, Alba NY, N.Y. USA. 
HALI, J. \& CLARKE, J.M., 1892: An introduction to the study of the Genera of Palaeozoic Brachiopoda, Geological survey of the State of New York, Palaeontology, $V$. VIII, Part I, Albany, N.Y., USA.

HALI, J. \& CLARKE, J.M., 1894: An introduction yo the study of the Genera of Palaeozoic Brachiopoda, Geological Survey of the state of New York, Palaeontology, $V$. VIII, part II, Albany, N.Y., USA.

HAMADA, T., 1971: Early Devonjan Brachiopods from the Lesser Khingan District of Northeast China, palaeontological. Society of Japan, Special papers, N. 15, Society, Japan.

HARPER JR.,C.V., BOUCOT,A.J. \& WAJMSLEY, V.G., 1969: The Rhipj.domellid Brachiopod Subfamilies Heterortininae and Platyorthinae (New), Journal of I'aleontology, V.43, N.1, USA. 
IMBRIE, J., 1959: Brachiopods of the Traverse Group (Devonian) of Michigan, part 1., Dalmane 1lacea, Pentameracea, strophomenacea, ox thotetacea, Chonetacea and Productacea, Bulletin of the American Museu of Natum ral History, V. I16, Article 4,N.Y.,USA.

JOHNSON, J.G., 1970: Great Basin Lower Devonian Bra chiopoda, Geological Society of America, Inc., Memoix 121, Boulder, Colorado, USA.

JOHNSON, J.G., 1971: A quantitative approach to fau nal province analysis, American Journal of Science, V. 270, USA.

KATZER, F., 1897: Das Amazonas-Devon und seine Bezi ehungen zu den anderen Devongebieten der Erde, sitzungsberichte der konigl. bohmi. schen, Gesellschaft der wissenschaften, Mathematisch - Natturwissenschaftliche.

KATZER, F., 1903: Grundzuge dex Geologie des unte... ren Amazonasgebietes, Verlag von Max Weg, tueipzig. 
KEGEL, W., 1953: Contribuiçäo para o estudo do Devo niano da Bacia do Parnaíba, DNPM, Boletim No 141, Rio de Janeiro, Brasil.

LANGE, F.W.1967: Subaivisão bioestratigräfica e re visão da coluna Silurompevoniana da Ba cia do baixo Amazonas, Atas do Simpösio sobre a Biota Amazônica, Geociências,V.1, pp. 215-300, Conselho Nacional de pesqui sas, Rio de Janeiro, Brasil.

IIDDLE, R.A., HARRIS,G.D. \& WELHLS,J.W., 1943: The Rio Cachiri Section in the Sierra de $\mathrm{Pe}$ rija, Venezuela, Bulletins of American Paleontology, V. 27, N. 108, Ithaca, New Yorke, USA.

MORALES, P.A., 1965: A contribution to the knowled ge of the devonian Faunas of Colombia, Boletin de Geologia No 19, pp. 51-114,De partamento de Geologia de La Facultad de Ingenieria de petroleos, Bucaramanga, Co Iombia. 


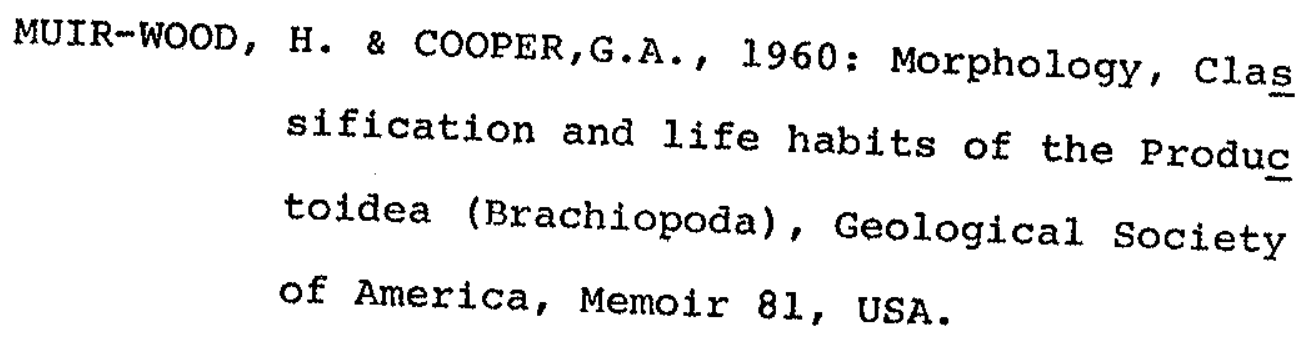

MUIR-WOOD,H., 1962: On the Morphology and classifi cation of the Brachiopod Suborder chone toidea, Britsh Museum (Natural History), London.

RATHBUN, R.,1874: On the Devonian Brachiopoda of Exe $x e$, Province of Para, Brazil, Morgan Ex peditions, 1870-1871, Bulletin of the Bu ffalo Society of Natural Science, USA.

RATHBUN, R., 1878: The Devonian Brachiopoda of the Province of Para, Brazil, Boston Society of Natural History, V. XX, USA.

SCHUCHERT, C. \& COOPER, G.A., 1932: Brachiopod Gene ra of the suborders Orthoidea and Penta meroidea, Memoirs of the Peabody Museum of Natural History, V. IV, part 1 , New Haven, Conn., USA. 
SCUPIN, H.,1900: Die Spiriferen Deutschlands, Pala eontologische Abhandlungen, Neue Folge Band IV (Der Ganzen Reihe Band VIII) Jena.

SHIMER, H.W. \& SHROCK, R.R., 1947: Index fossils of North America, A publication of the Tech nology press Massachusetts Institute of Technology, New.York: John Wiley \& Sons, Inc., USA.

SOLLE, G., 1971: Brachyspirifer im Rheinischen Devon, Abhandlungen des Hessischen Landesamtes fur Bodenforschung, Heft 59 , Wiesbaden.

TRAPP, D., 1968: Das Palaozoikum und Fruhmesozoikum im nordlichen Quetameund westlichen san tandermassiv der Ostkordillexe Kolumbiens, Sudamerika, private Veroffentlichung, Gi. essen, Juli.

TREATISE ON INVERTEBRATE PALEONTOLOGY, 1965:Geologi cal Society of America, Inc. and Univer- 
sity of Kansas Press, Directed and Edi ted by Raymund C. Moore, Brachiopoda, Part H, V.l e V.2, USA.

WALMESLEY, V.G. \& BOUCOT, A.J., 1971: The Ressere1 linae- a new subfamily of late ordovivi an to Early Devonian dalmanellid brachio pods, Palaeontology, V.14, Part 3, pala eontological Association, London.

WALMESLEY, V.G., BOUCOT,A.J. \& HARPER,C.W., 1969:S五 lurian and Lower Devonian Salopinid bra chiopods, Journal of Paleontology, V.43, N8 2 , pp. $492-516$.

WEDEKIND, R., 1926: Die devonische Formation in Sa loman, Wilhelm, Gxundzuge dex Geologie, V. 2: Stuttgart, E. Schweizerbast'sche, pp. $194-226$.

WEISBORD, N.E., 1926: Venezuelan Devonian Fossils, Bulletins of American Paleontology, V.II, NP 46, pp.221-268, Cornell university, Ithaca, N.Y., USA. 
WTLLIAMS, A., 1953: North American and European Stro pheodontids: Their Morphology and sistema tics, Geological Society of America, Memoir 56, USA. 